\title{
Sytuacja prawna i struktura terytorialna Kościoła katolickiego w Turcji
}

\author{
Legal status and territorial structure \\ of the Catholic Church in Turkey
}

\begin{abstract}
The problem of religious minorities, especially the Catholic Church in Turkey has not been widely discussed in literature. This paper reports the legal status and territorial structure of the catholic minority in Turkey in the context of general status of religious minorities in Turkey. The territorial structure of the Roman Catholic Church in Turkey, as well as other Eastern Catholic Churches is presented. Moreover, the distribution of parishes and churches is shown. Additionally, the analysis of historical and legal conditions that impact development and changes of Catholics' distribution in Turkey was undertaken.
\end{abstract}

Keywords: Turkey, Catholic Church, Eastern Catholic Churches, religious minority, religion and geography

\section{Wprowadzenie}

Sytuacja Kościoła katolickiego w Turcji jest tematem rzadko omawianym w literaturze. Do tej pory kwestie związane z Kościołem katolickim poruszane były najczęściej w pracach (m.in.: Yildiz 2007, Tokas, Aras 2009, Kościelniak 2010, Yilmaz 2012) oraz raportach (Oehring 2004, International Religious Freedom Report 2014) dotyczących ogólnej sytuacji i praw mniejszości religijnych w Turcji w kontekście jej członkostwa w Unii Europejskiej (UE). Problem praw i ochrony mniejszości religijnych jest nadal jednym z poważniejszych wyzwań w procesie 
integracji Turcji z UE (Szymański 2011, Yilmaz 2012). Jednak w ostatnich latach w związku z trudną sytuacją geopolityczną w regionie więcej uwagi poświęca się innym kwestiom niż mniejszości religijne. Obecnie w Turcji głównym problemem są jej wewnętrzne sprawy, takie jak konflikt kurdyjski oraz uchodźcy z Syrii i Iraku (Jarosiewicz, Strachota 2015). Ankara, prowadząc swoją politykę bliskowschodnią, również mocno angażuje się politycznie, a czasem nawet militarnie, w konflikty w Syrii i Iraku (Strachota 2015, Chudziak 2016). Głównie na tych sprawach koncentrują się politycy, media i społeczeństwo, a o mniejszościach religijnych lub etnicznych w Turcji mówi się przeważnie w kontekście niemuzułmańskich uchodźców (m.in. chrześcijan i jazydów) z Syrii i Iraku.

W niniejszym artykule omówiono sytuacje prawną i strukturę terytorialną Kościoła katolickiego w Turcji. W pierwszej części przedstawiono problematyke związaną z uwarunkowaniami prawnymi i historycznymi, które mają wpływ na sytuację Kościoła katolickiego, a także innych mniejszości religijnych w Turcji. Następnie przeprowadzono analizę struktury terytorialnej Kościoła katolickiego, która opiera się na opisie zmian przebiegu granic jednostek kościelnych, charakterystyce przestrzennego rozmieszczenia parafii i świątyń katolickich oraz liczby i rozmieszczenia katolików. Przedstawiono również szczegółową charakterystykę poszczególnych jednostek kościelnych dla wszystkich Kościołów katolickich (w tym również katolickich Kościołów wschodnich) działających na terenie Turcji.

\section{Mniejszości religijne $\mathrm{w}$ imperium osmańskim w dwudziestoleciu międzywojennym}

Imperium osmańskie przez kilka stuleci swojego istnienia zajmowało ogromny obszar od Mezopotamii przez Egipt aż po Półwysep Bałkański. Państwo osmańskie mimo dominującej roli islamu i obowiązywania prawa islamskiego (szariatu) było państwem multikulturowym i wielonarodowościowym. Funkcjonowało dzięki systemowi politycznemu opartemu na miletach (tur. milliyet), czyli wspólnotach religijnych, które posiadały dużą wewnętrzną autonomię i były zarządzane przez przywódców duchowych. System określał prawa i obowiązki ludności niemuzułmańskiej. Zasadniczo w sferze religii i kultury pozostawiano znaczną swobodę każdej z grup religijnych. Wiązało się to jednak z pewnymi obowiązkami. Jednym z nich były podatki, wyższe dla ludności niemuzułmańskiej (Kołodziejczyk 2011). System miletów powstał w XV w., a za jego inicjatora uważa się sułtana 
Mehmeta II Zdobywcę, który mianował patriarchę prawosławnego oraz patriarchę ormiańskiego zwierzchnikami cywilnymi dla wszystkich wiernych tych Kościołów. Każdy z wyznaczonych przez sułtana przywódców religijnych posiadał władzę świecką w zakresie sądowniczym i podatkowym nad podległym sobie „narodem”. Mniejszości religijne często bowiem nazywano „narodami” (Kościelniak 2010).

W 1885 r. imperium osmańskie zamieszkiwało 17 mln 375 tys. osób, z czego 27\% (4 mln 670 tys.) stanowiła ludność niemuzułmańska. Byli to głównie prawosławni Grecy i Bułgarzy oraz Ormianie należący do Ormiańskiego Kościoła Apostolskiego. Kościół katolicki w tym czasie liczył 168 tys. wiernych, przede wszystkim greckich i ormiańskich katolików (Shaw 1978, Karpat 1985). Dzięki systemowi miletów kolejni władcy imperium mogli bez większych trudności panować na bardzo rozległym i zróżnicowanym etnicznie oraz kulturowo obszarze. Jednak rosnąca świadomość narodowa i rodzące się w całej Europie od końca XIX w. nacjonalizmy sprawiły, że system miletów oparty na przynależności religijnej zaczął być niewystarczający. Osłabienie ich znaczenia w zarządzaniu krajem oraz wybuch I wojny światowej, doprowadziło do rozpadu imperium (Wódka 2012).

W 1923 r. Zgromadzenie Narodowe proklamowało Republike Turecką. Wprowadzenie nowego ustroju politycznego (republiki) spowodowało zniesienie sułtanatu, sekularyzacje państwa i rezygnację z dotychczasowego systemu prawnego opartego na prawie islamskim. Dzięki temu Turcja stała się pierwszym na świecie państwem muzułmańskim o charakterze laickim (Kołodziejczyk 2011). Nowo odradzające się państwo tureckie zdołało zachować część terytorium dawnego imperium, tym samym przejęło część jego kulturowej różnorodności. Jednak zdecydowana większość niemuzułmańskich mieszkańców imperium zginęła w czasie I wojny światowej lub wyemigrowała w jej trakcie albo niedługo po jej zakończeniu. Transformacja z islamskiej monarchii w świecką republikę i zwrócenie się państwa w kierunku Zachodu nie przyniosły oczekiwanych korzyści dla niemuzułmańskich obywateli, którzy po I wojnie światowej pozostali na terenie Turcji. Idea laickiego państwa Atatürka, przynajmniej w teorii, polegała przede wszystkim na rozdzieleniu państwa od religii, pomijając przy tym sprawy mniejszości religijnych i etnicznych. W pierwszych latach działania republiki skupiono się głównie na odsunięciu islamistów od władzy i odebraniu im dotychczasowych przywilejów, przy okazji zabierając je także mniejszościom religijnym (Haynes 2010).

Dopiero rozpoczęty przez Turcję w 1959 r. proces negocjacyjny z UE, a szczególnie otwarcie w 2005 r. na nowo negocjacji, wymusiły na władzach tureckich 
zainteresowanie się problemem mniejszości religijnych. Proces akcesyjny Turcji do UE i związane z tym stopniowe wypełnianie zobowiązań i przyjmowanie standardów zachodnioeuropejskich w pewnym stopniu pomogło rozpocząć działania mające na celu osiągnięcie porozumienia między państwem a niemuzułmańskimi społecznościami religijnymi. Jednak wyzwania polityczne przed jakimi stoi obecnie Turcja, m.in. problem kurdyjski, status Cypru Północnego czy wojna domowa w Syrii i Iraku, sprawiają, że sprawy dotyczące statusu mniejszości religijnych wciąż schodzą na dalszy plan (Szymański 2011).

\section{Mniejszości religijne w Turcji}

Współcześnie Turcja jest krajem muzułmańskim, niemal jednolitym religijnie. Wyznawcy islamu stanowią ponad 99\% ludności (International Religious Freedom Report 2014). Większość muzułmanów to sunnici, jednak w ramach szeroko rozumianego islamu istnieje kilka różnych grup i odłamów. Obecnie spośród muzułmańskich mniejszości można wyróżnić przede wszystkim alewitów i szyitów (Kościelniak 2010). Alewici tworzą dużą grupę etniczno-wyznaniową. Szacuje się, że stanowią oni od 10 do 30\% wszystkich muzułmanów w Turcji. Trudności w oszacowaniu ich liczby wynikają z faktu, że w Turcji formalnie nie uznaje się istnienia mniejszości muzułmańskich. Dlatego też nie prowadzi się oficjalnych statystyk dotyczących struktury religijnej społeczeństwa. Dotyczy to wszystkich mniejszości religijnych, stąd pojawiają się problemy w określeniu ich liczby (Zeidan 1999).

Ocenia się, że w Turcji jest od 150 tys. do 350 tys. niemuzułmanów, co stanowi ok. 0,4\% ludności. W rzeczywistości nieislamska mniejszość może być liczniejsza, gdyż w kraju tym żyje nadal duża liczba zislamizowanych Ormian, Asyryjczyków oraz innych narodowości. Część z tych osób próbuje dokonać konwersji z powrotem na chrześcijaństwo. Jest to dość skomplikowana procedura prawna, a władze nie są jej przychylne. Mimo to w ostatnich kilkunastu latach do świeckich sądów w całej Turcji wpłynęło ponad tysiąc spraw dotyczących konwersji na chrześcijaństwo oraz zmiany imienia na chrześcijańskie (Özgül 2014).

Wśród niemuzułmańskich mniejszości religijnych najliczniejszą grupę stanowią chrześcijanie różnych wyznań, w zależności od źródła danych jest ich od 150 tys. do 250 tys. osób, kolejną wspólnotą religijną są żydzi (22 tys.). Na terenie Turcji mieszkają też przedstawiciele innych religii, m.in. bahaici i jazydzi - obecnie duża 
część z nich to uchodźcy przybywający w ostatnich latach z Syrii i Iraku (Oehring 2004, International Religious Freedom Report 2014).

Według International Religious Freedom Report (2014) największymi grupami wśród chrześcijan są wyznawcy: Apostolskiego Kościoła Ormiańskiego (90 tys.), Kościoła Rzymskokatolickiego (25 tys.), Syryjskiego Kościoła Ortodoksyjnego (20 tys.), Rosyjskiego Kościoła Prawosławnego (15 tys.) oraz protestanci (7 tys.). Pozostałe wyznania i społeczności chrześcijańskie to m.in. Świadkowie Jehowy ${ }^{1}$. (5 tys.), chaldejscy chrześcijanie (3 tys.), prawosławni Grecy (2,5 tys.) oraz mniejsze społeczności, takie jak chrześcijańscy nestorianie, Gruzini oraz syryjscy i ormiańscy katolicy.

W zależności od źródła dane dotyczące liczebności różnych grup religijnych różnią się między sobą. Najmniej wątpliwości pojawia się w kontekście liczby wiernych Kościoła katolickiego. Najbardziej wiarygodnym źródłem są tu watykańskie roczniki statystyczne tzw. Annuario Pontificio, częściowo publikowane w Internecie (Kościelniak 2010). Jednak przy porównaniu ich z danymi z różnego typu raportów pojawiają się pewne rozbieżności. Jedną z przyczyn może być dynamicznie zmieniająca się liczba katolików spowodowana różnego typu migracjami. Część katolików to osoby przebywające w Turcji tymczasowo, dodatkowo w niektórych statystykach liczeni są katoliccy imigranci z Afryki i Filipin, a w innych już nie (International Religious Freedom Report 2014). Sprawę określenia dokładnej liczby wiernych utrudnia także skomplikowana struktura organizacyjna Kościoła katolickiego. Aktualnie w Turcji działa pięć katolickich Kościołów wschodnich, zdarza się, że w niektórych zestawieniach nie są one brane pod uwage. Według danych z roczników watykańskich (Annuario Pontificio 2014) liczba wiernych Kościoła katolickiego w Turcji (wliczając wiernych wszystkich obrządków) wynosiła w 2014 r. 46330 osób (www 1).

1 Świadkowie Jehowy są związkiem wyznaniowym zaliczanym do ruchu restoracjonistycznego, wywodzącego się z protestantyzmu. Jednak przynależność do chrześcijaństwa Świadków Jehowy, jak i innych wyznań restoracjonistycznych, jest często kwestionowana, głównie ze względów doktrynalnych: odrzucenia przez Świadków Jehowy tradycji katolickiej i protestanckiej (m.in. brak wiary w Trójcę Świętą, inna forma chrztu świętego czy wreszcie odmienna interpretacja Biblii). 


\section{Status prawny Kościoła katolickiego w Turcji}

W świetle obowiązujących przepisów prawnych sytuacja społeczności niemuzułmańskich w Turcji jest niezwykle skomplikowana. Przepisy są niejednolite i zmieniają się w zależności od tego, jakiej wspólnoty religijnej dotyczą (Oehring 2004, Kościelniak 2010). W Turcji obowiązuje kilka kluczowych aktów prawnych, które określają status mniejszości. Są to: traktat lozański $(1923)^{2}$, konstytucja Turcji (1982) oraz ratyfikowane akty prawa międzynarodowego: Powszechna Deklaracja Praw Człowieka ONZ z 1948 r. oraz Deklaracja ONZ w sprawie Eliminacji Wszelkich Form Nietolerancji i Dyskryminacji Opartych na Religii lub Przekonaniach z 1981 r. (Yildiz 2007). Konstytucja turecka i inne akty prawne, mimo dość dużej liczby przepisów, są aktami ogólnymi i na ogół nie wymieniają żadnych konkretnych mniejszości etnicznych czy religijnych. Najbardziej szczegółowe przepisy dotyczące mniejszości znajdują się w traktacie lozańskim (Oehring 2004). Jednak również tutaj nie sprecyzowano jakie dokładnie mniejszości obejmuje ten dokument. Niedługo po podpisaniu traktatu Turcja uznała, że jedynie Ormianie, Grecy i Żydzi mogą być uznani za mniejszości i tym samym tylko te społeczności mogą korzystać z praw zapisanych $\mathrm{w}$ traktacie. Wymienione mniejszości to równocześnie trzy największe wspólnoty religijne istniejące w imperium osmańskim (poza dominującym islamem) i odpowiadające wspomnianym wcześniej miletom. Pozostałych niemuzułmańskich społeczności traktat lozański nie dotyczył. Niektóre z nich, na przykład wyznawcy Asyryjskiego Kościoła Wschodu, Kościoła chaldejskiego czy nestorianie, nie były włączone do osmańskiego systemu miletów, dlatego też nie brano pod uwagę możliwości, by objąć te grupy przepisami traktatu. Nie jest jednak do końca jasne, dlaczego pozostałe mniejszości religijne, takie jak Kościół katolicki, Syryjski Kościół Prawosławny, jazydzi czy bahaici, nie zostały uwzględnione przez władze tureckie, mimo że były uznawane przez sułtana jako milety (Toktas, Aras 2009). Od 1923 r. Turcja nie poczyniła żadnych zmian w interpretacji i stosowaniu traktatu lozańskiego, z jednym niedużym wyjątkiem, kiedy w 1925 r. podpisano bułgarsko-turecki traktat o przyjaźni. Dzięki temu dodano Bułgarów do

2 Traktat pokojowy zawarty 24 lipca 1923 r. w Lozannie pomiędzy przedstawicielami Wielkiej Brytanii, Francji, Włoch, Japonii, Rumunii, Królestwa SHS, Bułgarii, Grecji i Turcji. Zakończył on wojnę grecko-turecką oraz zrewidował postanowienia traktatu z Sèvres z 1920 r. 
trzech wcześniej uznanych mniejszości. Nie zmieniło to jednak ogólnej sytuacji mniejszości religijnych, ponieważ Bułgarzy nie byli i nie są także dzisiaj liczną grupą (Oehring 2004).

Obecnie Kościół katolicki wraz ze swoimi Kościołami wschodnimi nie jest oficjalnie uznawany przez władze tureckie za mniejszość religijną, dlatego nie dotyczą go przepisy traktatu lozańskiego. W związku z tym jest on pozbawiony osobowości prawnej, nie może prowadzić normalnej działalności religijnej oraz nabywać nieruchomości i nimi dysponować. Z punktu widzenia władz tureckich zarówno diecezje, jak i zakony oraz zgromadzenia działające w Turcji nie mają statusu prawnego. Chociaż w niektórych sprawach biskupi są traktowani przez niektóre instytucje państwowe (np. gubernatora danej prowincji) jako liderzy swoich wspólnot religijnych (Oehring 2004). Osobliwy jest również fakt, że Watykan utrzymuje stosunki dyplomatyczne z Republiką Turcji już od ponad 60 lat. Przedstawicielem Watykanu w Ankarze jest nuncjusz apostolski. Jednocześnie władze tureckie oficjalnie nie uznają istnienia żadnych innych struktur Kościoła katolickiego. Powoduje to niejasną sytuację, w której rząd turecki tworzy rozróżnienie między Stolicą Apostolską, a działającymi na terenie Turcji jednostkami i instytucjami kościelnymi.

Większość kościołów, klasztorów oraz innych nieruchomości kościelnych (np. cmentarzy) jest administrowana za pośrednictwem różnego typu fundacji, które w pewnym sensie omijają prawo i zajmują się także opieką nad wspólnotami religijnymi (Kościelniak 2010). Jest to sposób, by zachować kontrolę nad kościołami, szkołami (które oficjalnie nie mogą działać nawet w ramach fundacji) oraz innymi obiektami. Staje się to jednak coraz trudniejsze, szczególnie na wschodzie i południowym wschodzie Turcji, gdzie i tak mało już liczne wspólnoty Asyryjczyków i Ormian emigrują za granicę lub do większych miast, głównie Stambułu i Ankary. Tamtejsze kościoły pustoszeją, są sporadycznie użytkowane i niszczeją. Z tego względu władze tureckie często je konfiskują i zamykają lub w wyjątkowych przypadkach przekształcają w muzea (International Religious Freedom Report 2014).

Trzeba pamiętać, że większość nieruchomości kościelnych została zabrana przez państwo już w dwudziestoleciu międzywojennym, w czasie tworzenia laickiego państwa Atatürka. Wiele z nich jest aktualnie zamkniętych lub użytkowanych przez władze państwowe w innych celach niż sakralne albo sprzedanych osobom prywatnym. Tylko część świątyń należących obecnie do państwa jest sporadycznie udostępniana na potrzeby niektórych wspólnot religijnych. 
W ostatnich latach Kościół katolicki w Turcji przedstawił listę ponad 200 nieruchomości (kościołów, szkół, domów dziecka, szpitali i cmentarzy), które w czasie istnienia imperium osmańskiego były jego własnością. Powstała ona na podstawie spisu sporządzonego w 1913 r. pomiędzy wielkim wezyrem i Francją, która wtedy reprezentowała Kościół katolicki (www 2). Sprawa zwrotu skonfiskowanych nieruchomości należących do niemuzułmańskich mniejszości religijnych jest jednym z często poruszanych problemów we wzajemnych relacjach Turcji z Unią Europejską. W ostatnich latach UE wymogła na Turcji podjęcie działań w celu usunięcia lub zmiany części przepisów dyskryminujących mniejszości religijne. W niektórych przypadkach w działania te włącza się Europejski Trybunał Praw Człowieka, który krytykuje państwo tureckie i w imieniu poszkodowanych wspólnot występuje o zwrot majątku lub wypłatę rekompensat (Kościelniak 2010). Działania te odniosły tylko częściowy skutek, ponieważ w 2011 r. rząd turecki wydał dekret dotyczący odszkodowań i zwrotu skonfiskowanych majątków należących do mniejszości religijnych. Jest to krok w dobrą stronę, jednak restytucja i odszkodowania założone w dekrecie nie obejmują Kościoła katolickiego. Ponownie uwzględniono jedynie mniejszości uznane w ramach traktatu lozańskiego (Hovyan 2013).

\section{Struktura terytorialna i organizacyjna Kościoła katolickiego w Turcji}

\subsection{Współczesny podział Kościoła katolickiego}

Obecnie na terenie Turcji działa osiem jednostek administracyjnych (diecezje, wikariaty) Kościoła Rzymskokatolickiego różnych obrządków. W ich ramach funkcjonują 54 parafie, kilka ośrodków duszpasterstwa, szpitale oraz szkoły katolickie (Tab. 1). Według danych watykańskich (Annuario Pontificio) z 2014 r. całe duchowieństwo w Turcji liczyło: czterech księży biskupów, 13 kapłanów diecezjalnych i 56 zakonnych oraz dwóch diakonów stałych, ośmiu braci zakonnych i 54 zakonnice. W kraju tym pracują m.in. franciszkanie, dominikanie, kapucyni assumpcjoniści, lazaryści, salezjanie, Siostry Szkolne De Notre Dame oraz misjonarze świeccy i katecheci (www 1). Wszystkie relacje między placówkami kościelnymi - od parafii przez diecezje po biskupów oraz różne instytucje kościelne - są regulowane przez prawo kanoniczne. Jednak, jak 
Tab. 1. Podział administracyjny Kościoła katolickiego w Turcji (stan na 2014 r.)

\begin{tabular}{|c|c|c|c|c|c|}
\hline & $\begin{array}{c}\text { Kościół } \\
\text { (ryt, obrządek) }\end{array}$ & Nazwa jednostki & $\begin{array}{l}\text { Liczba } \\
\text { parafii }\end{array}$ & $\begin{array}{l}\text { Liczba } \\
\text { kościołów }\end{array}$ & $\begin{array}{l}\text { Liczba } \\
\text { wiernych }\end{array}$ \\
\hline & & $\begin{array}{l}\text { Wikariat apostolski } \\
\text { Stambułu }\end{array}$ & & & \\
\hline & & $\begin{array}{l}\text { Siedziba: Stambuł, } \\
\text { Katedra Ducha Św. }\end{array}$ & 10 & 20 & 1000 \\
\hline & 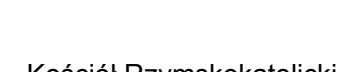 & $\begin{array}{l}\text { Archidiecezja } \\
\text { Izmirska }\end{array}$ & & & $150 \cap 00$ \\
\hline & 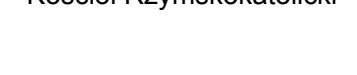 & $\begin{array}{l}\text { Siedziba: Izmir, } \\
\text { Katedra św. Jana }\end{array}$ & 11 & 10 & 10000 \\
\hline & & $\begin{array}{l}\text { Wikariat apostolski } \\
\text { Anatolii }\end{array}$ & & & \\
\hline & & $\begin{array}{l}\text { Siedziba: Iskande- } \\
\text { run, Katedra WNMP }\end{array}$ & 0 & 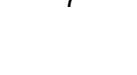 & 2000 \\
\hline 2 & Ormiański Kościół Katolicki & $\begin{array}{l}\text { Archieparchia } \\
\text { Konstantynopola }\end{array}$ & 10 & 12 & 3200 \\
\hline & (ryt ormiański) & $\begin{array}{l}\text { Siedziba: Stambuł, } \\
\text { Katedra NMP }\end{array}$ & ro & & 2000 \\
\hline & Chaldejski Kościół Katolicki & $\begin{array}{l}\text { Archieparchia } \\
\text { Diyarbakır (Amida) }\end{array}$ & & & \\
\hline U. & (ryt chaldejski) & $\begin{array}{l}\text { Siedziba: Diyarbakir, } \\
\text { Katedra NMP }\end{array}$ & 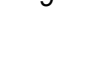 & 2 & 1040 \\
\hline & Grecki Kościół Katolicki & $\begin{array}{l}\text { Egzarchat apostolski } \\
\text { Stambułu }\end{array}$ & & & \\
\hline 4. & (ryt bizantyjski) & $\begin{array}{l}\text { Siedziba: Stambuł, } \\
\text { Katedra św. Trójcy }\end{array}$ & 1 & 1 & $\angle U$ \\
\hline 5. & Syryjski Kościół Katolicki & $\begin{array}{l}\text { Egzarchat patriarszy } \\
\text { Turcji }\end{array}$ & 3 & 3 & 2000 \\
\hline & & Siedziba: Stambuł & & & \\
\hline 6. & $\begin{array}{l}\text { Grecki Melchicki } \\
\text { Kościół Katolicki }\end{array}$ & $\begin{array}{l}\text { Egzarchat patriarszy } \\
\text { Stambułu }\end{array}$ & 1 & $0^{*}$ & 20 \\
\hline & (ryt bizantyjski) & Siedziba: Stambuł & & & \\
\hline 7. & Razen & & 54 & 62 & 46330 \\
\hline
\end{tabular}

Źródło: opracowanie własne na podstawie: www.catholic-hierarchy.org; www.gcatholic.or oraz www.cnewa.org (dostęp 15.12.2015). 
wspomniano wcześniej, Republika Turecka oficjalnie nie uznaje ich istnienia na swoim terytorium.

Najbardziej rozbudowane struktury posiada Kościół Rzymskokatolicki obrządku łacińskiego, w ramach którego działają dwa wikariaty i jedna archidiecezja (tab. 1). Są one bezpośrednio podległe Stolicy Apostolskiej (Kościelniak 2010). Oprócz tego w Turcji działa pięć jednostek katolickich Kościołów wschodnich. Są one autonomicznymi wspólnotami, Kościołami partykularnymi, które pozostają w unii ze Stolicą Apostolską i uznają autorytet oraz władzę papieża. Kościoły wschodniokatolickie ze względu na tradycję liturgiczną można podzielić na pięć rytów (obrządków): chaldejski (wschodniosyryjski), antiocheński (zachodniosyryjski), aleksandryjski, ormiański oraz bizantyjski. Pod względem doktrynalnym przyjmują one naukę Kościoła katolickiego, jednocześnie zachowując prawa i tradycje liturgiczne, szczególnie sposób modlitwy i odprawiania mszy świętej, Kościołów wschodnich, z których się wyodrębniły. Pod względem formalnym Kościoły wschodnie działają na podstawie dekretu o katolickich Kościołach wschodnich z 1964 r. oraz Kodeksu Kanonów Kościołów Wschodnich z 1990 r. Według tych dokumentów wszystkie Kościoły mają takie same prawa i obowiązki oraz jednakową godność i żaden $z$ nich nie dominuje nad innymi $z$ racji obrządku. Zorganizowane są w patriarchaty, arcybiskupstwa i metropolie, które są zarządzane i nazywane według własnej tradycji, np. eparchia i egzarchat to odpowiedniki rzymskokatolickiej diecezji (Roberson 1998, Nitkiewicz 2014).

W Turcji działa obecnie pięć Kościołów wschodniokatolickich: Ormiański Kościół Katolicki, Chaldejski Kościół Katolicki, Grecki Kościół Katolicki, Grecki Melchicki Kościół Katolicki oraz Syryjski Kościół Katolicki - należą one do różnych obrządków (tab. 1). Ze względu na odmienną kulturę oraz wielowiekową tradycję i historię wspólnoty te należy uznać jako osobne mniejszości religijne działające w ramach struktur Kościoła katolickiego. Historia i tradycja tych Kościołów jest dużo starsza niż ich współcześnie działające struktury kościelne i często obejmuje początki chrześcijaństwa.

\subsection{Historyczny rozwój struktur Kościoła Rzymskokatolickiego}

Chrześcijaństwo na terenie Azji Mniejszej ma długą tradycję i sięga pierwszych wieków naszej ery. Za początek kształtowania się współczesnych struktur Kościoła katolickiego w Turcji można uznać utworzenie przez papieża Klemensa VI w 1346 r. 
katolickiej archidiecezji w Smyrnie (obecnie Izmir). W 1575 r. została ona przemianowana na arcybiskupstwo tytularne, co łączyło się z praktycznym zaprzestaniem jej działalności. W 1625 r. wznowiono jej funkcjonowanie, ale zmniejszono rangę do poziomu wikariatu apostolskiego. Niedługo później powstały dwie nowe jednostki kościelne w tym regionie. W 1628 r. utworzono misję sui iuris dla Syrii i Cylicji, obejmującą południowo-wschodnie obszary imperium osmańskiego, czyli obecne obszary południowo-wschodniej Turcji, północnej Syrii oraz częściowo północnego Iraku. Misja ta w 1817 r. została podniesiona do rangi prefektury apostolskiej. Drugą jednostką kościelną był wikariat apostolski Konstantynopola ustanowiony w 1652 r. (www 3). W 1818 r. w Smyrnie ponownie ustanowiono siedzibę arcybiskupstwa, bezpośrednio podległego Stolicy Apostolskiej.

Kolejnym krokiem w budowaniu i organizowaniu struktur Kościoła Rzymskokatolickiego na tym obszarze było utworzenie nowych jednostek terytorialnych. W 1842 r. powołano prefekturę apostolską w Mardin, która częściowo przejęła tereny do tej pory administrowane przez prefekturę apostolską Syrii i Cylicji. W 1845 r. z części terytorium wikariatu Konstantynopola utworzono prefekture apostolską Trabzonu (www 4). W kolejnych latach ponownie zmieniano granice jednostek kościelnych (ryc. 1). W 1896 r. w związku z trudnościami organizacyjnymi zlikwidowano wszystkie prefektury, a ich terytoria włączono do wikariatów i archidiecezji. Prefektura apostolska Mardin została przyłączona do archidiecezji bagdadzkiej, prefektura Syrii i Cylicji do wikariatu Aleppo, a prefekturę Trabzonu włączono do wikariatu apostolskiego Konstantynopola. Kolejne zmiany granic nastąpiły w $1931 \mathrm{r}$. - z terytorium wikariatu Konstantynopola wydzielono misje „sui iuris” z siedzibą w Trabzonie. W 1939 r. po zajęciu przez Republikę Turecką prowincji Hatay, należącej od 1920 r. do Syrii, Watykan zdecydował, że część dotychczasowego terytorium wikariatu Aleppo, położonego od tej pory na terenie Turcji, zostanie włączona do wikariatu Konstantynopola.

\subsection{Współczesny podział Kościoła rzymskokatolickiego}

Współczesny podział terytorialny Kościoła Rzymskokatolickiego w Turcji został ustanowiony w $1990 \mathrm{r}$. Obecnie działają tu dwa wikariaty i jedna archidiecezja (tab. 1). W 1990 r. dokonano kilku istotnych zmian w ówczesnej kościelnej strukturze administracyjnej. Kluczową było podniesienie na mocy dekretu Quo melius Kongregacji ds. Kościołów Wschodnich z dnia 30 listopada 1990 r. misji sui iuris w Trabzonie do rangi wikariatu apostolskiego Nowo utworzony wikariat objął 

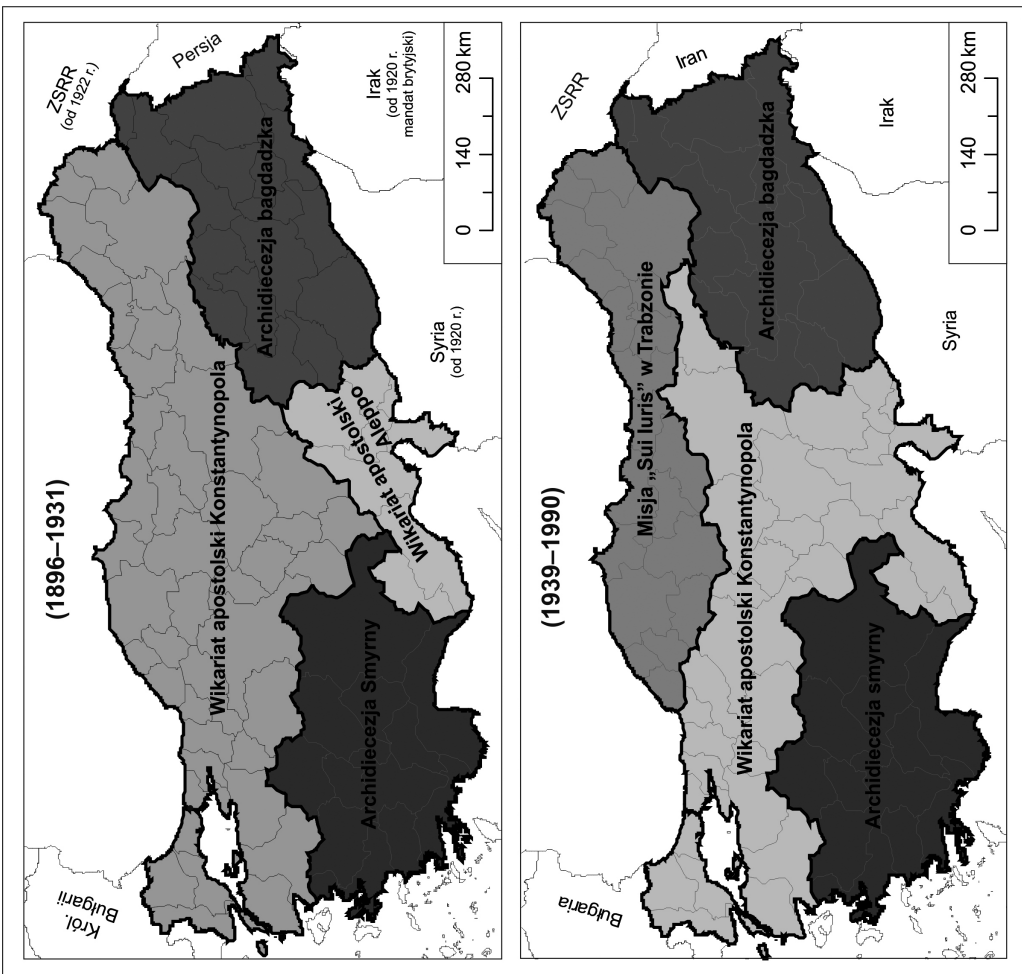

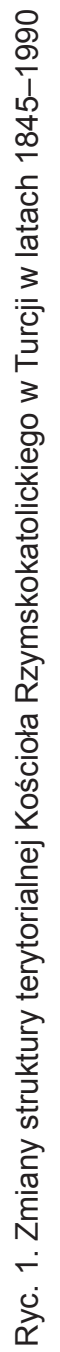
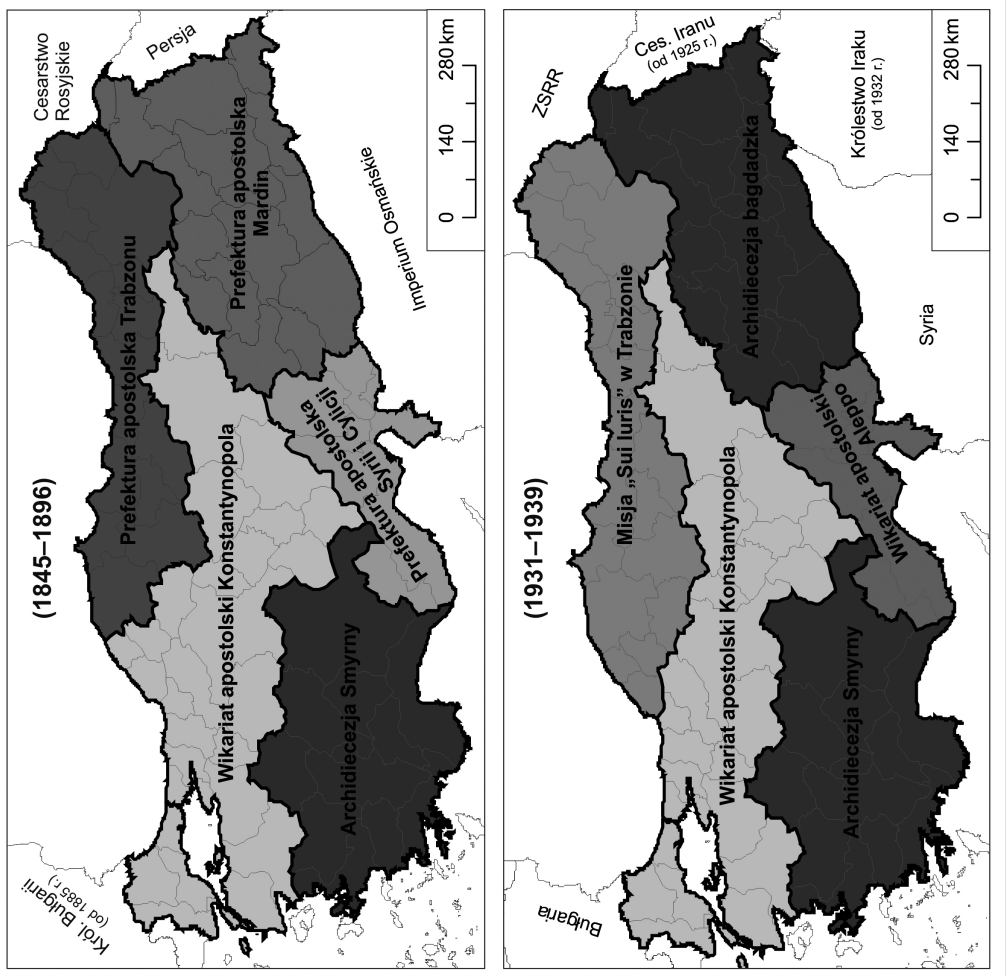
swoim zasięgiem duży obszar: centralną i południową część Anatolii (wcześniej należącą do wikariatu apostolskiego Konstantynopola), wschodnią część Anatolii (poprzednio archidiecezja bagdadzka) oraz północną część wybrzeża Morza Czarnego (ryc. 1, ryc. 2). Początkowo siedzibę wikariusza apostolskiego ustanowiono w Mersin. Po niespełna dziesięciu latach 29 czerwca 2000 r. przeniesiono ją do Iskenderun, a w Mersin pozostała konkatedra (www 5). W 1990 r. oficjalnie zmieniono również nazwę z archidiecezji Smyrny na archidiecezję Izmiru (ryc. 2).

W 2014 r. wśród rzymskokatolickich jednostek kościelnych największą liczbę wiernych (15 650 osób) posiadał wikariat apostolski Stambułu. Byli to głównie mieszkańcy Stambułu i Ankary. W wikariacie czynne są 23 kościoły, z czego 18 w samym Stambule, cztery w Ankarze i jeden w Bursie (ryc. 2). Większość obecnie działających świątyń została zbudowana lub gruntownie przebudowana w XIX w., a najstarsze (np. kaplica św. Benedykta) pochodzą z XV w. (tab. 2). Siedzibą biskupa jest katedra pw. Ducha Świętego. Jest to drugi co do wielkości kościół rzymskokatolicki w Stambule, po bazylice św. Antoniego z Padwy w dzielnicy Beyoğlu (fot. 1, ryc. 3). Trzynaście kościołów ma status świątyń parafialnych, wszystkie znajdują się w Stambule (tab. 2). Część z nich ma charakter kościołów „narodowych” . Swoje świątynie mają: Niemcy, Austriacy, Francuzi i inne narodowości. Zlokalizowane są one głównie w dwóch dzielnicach: Beyoğlu i Beşiktaş (ryc. 3). Jest to związane z historią i powstaniem tych dzielnic, były one ulokowane na obrzeżach starego miasta i pałacu suttana. W XIX w. większość mieszkańców dzielnicy Beyoğlu stanowili niemuzułmanie, głównie Grecy, Ormianie, Żydzi oraz europejscy kupcy, przedsiębiorcy i dyplomaci z rodzinami (do chwili przeniesienia stolicy do Ankary w 1923 r. mieściła się tu większość ambasad). Była to najnowocześniejsza i najbardziej europejska dzielnica ówczesnego Konstantynopola. Dlatego budowano tutaj większość kościołów, część $z$ nich powstała przy ambasadach, a przy parafiach lub klasztorach tworzono katolickie szkoły. Natomiast Beșiktaș w tamtym czasie był atrakcyjną dzielnicą willową, również zamieszkaną przez różne narodowości, głównie Greków i Żydów (Cleav, Freely 2008). W Stambule działa także polski kościół pw. Matki Bożej Częstochowskiej, położony na terenie dawnej wsi Polonezköy (Adampol) (www 3).

Obecnie w stambulskich kościołach msze św. odbywają się w różnych językach, np. w bazylice św. Antoniego jest to język włoski, angielski, turecki i polski. Wierni wikariatu to $w$ dużej części obcokrajowcy przybywający do Turcji (głównie do Stambułu i Ankary) z Europy na pobyt czasowy w celach zarobkowych, biznesowych, na wymiany i staże naukowe lub są to osoby posiadające podwójne obywatelstwo, np. turecko-włoskie (Oehring 2004). 


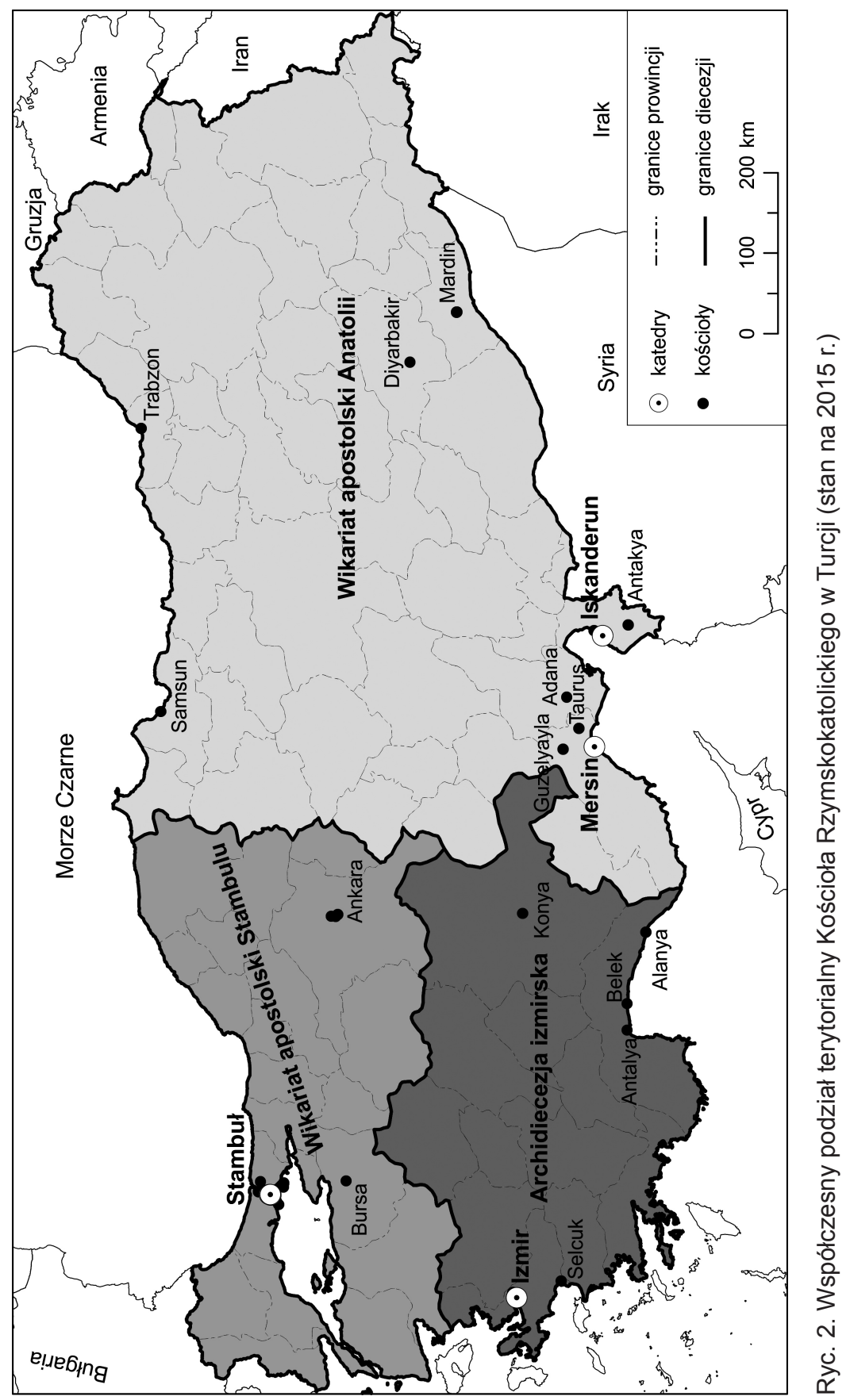



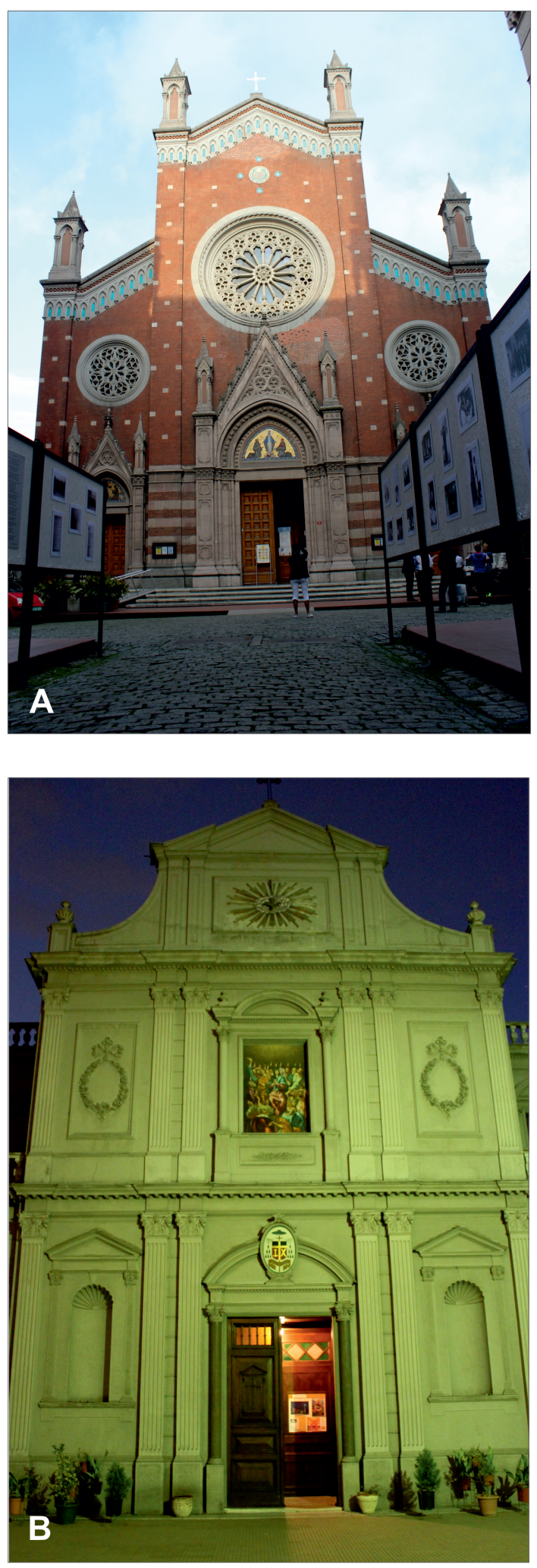

Fot. 1. Kościoły rzymskokatolickie w Stambule: A - bazylika św. Antoniego z Padwy, największy kościół rzymskokatolicki w Stambule; B - katedra Ducha Św. (fot. M. Jakiel) 


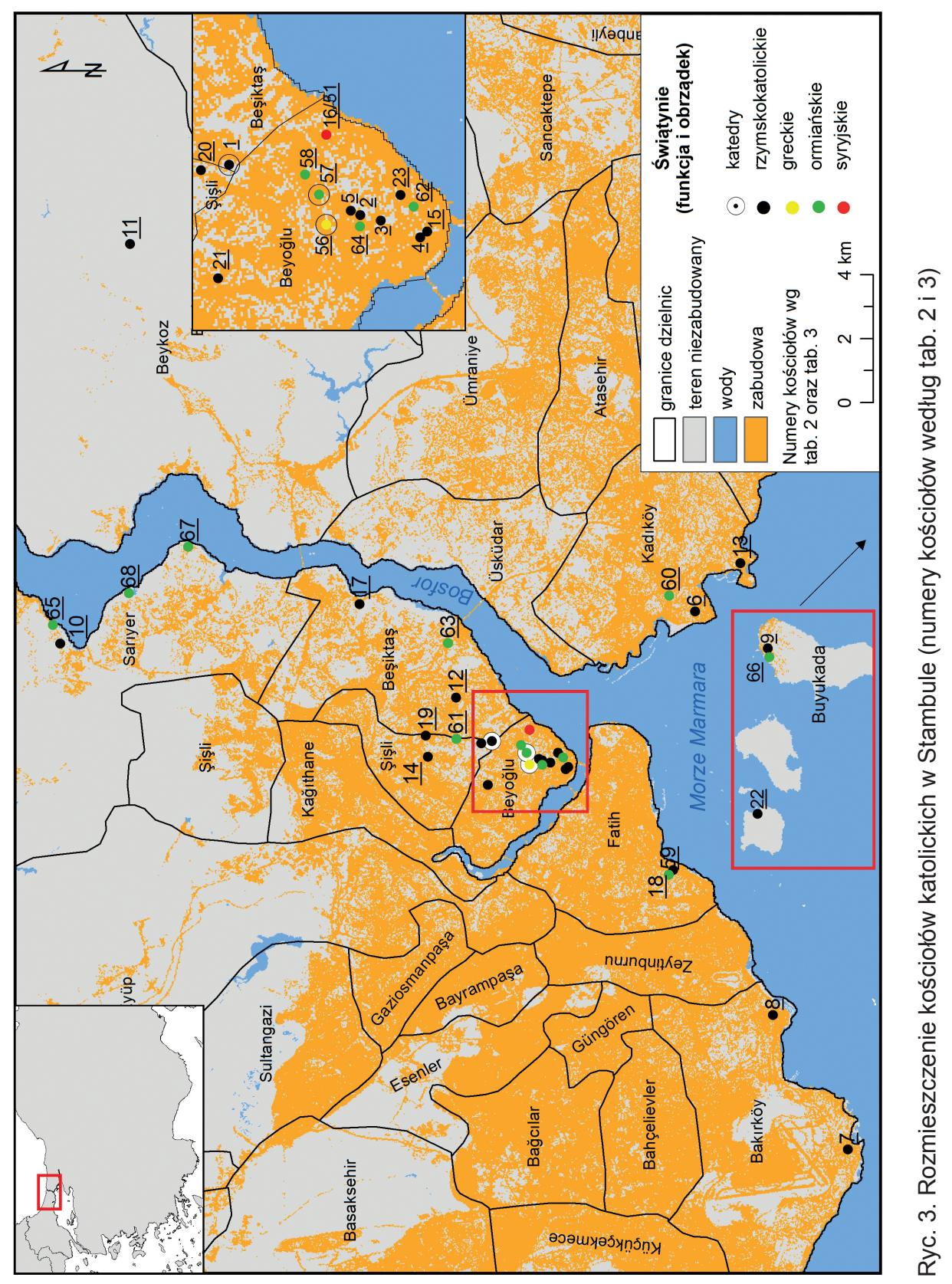


Archidiecezja izmirska swoim zasięgiem obejmuje zachodnią część Turcji (ryc. 2), na jej terenie mieszka 15 tys. katolików. Działa od 1346 r. i jest najstarszą istniejącą jednostką administracyjną Kościoła katolickiego w Turcji. Głównym kościołem jest katedra pw. św. Jana w Izmirze. Archidiecezja posiada 11 parafii obsługiwanych przez 13 kościołów, z czego dziewięć znajduje się w Izmirze. W większości są to świątynie z XIX w., wzniesione dla mniejszości katolickiej zamieszkującej ówczesną Smyrnę (tab. 2). Kościoły w Antalyi, Alanyi oraz Belek powstały kilka lat temu i mają na celu głównie obsługę turystów zagranicznych. Na terenie archidiecezji znajduje się sanktuarium domku Matki Bożej „Dom Dziewicy Marii” (tur. Meryemana), położone kilka kilometrów od Efezu. Według tradycji właśnie w tym miejscu znajdował się dom, w którym po śmierci Jezusa mieszkała Matka Boska. Pielgrzymują tu zarówno chrześcijanie, jak i muzułmanie (www 6). W trakcie swoich pielgrzymek po Turcji miejsce to odwiedziło trzech papieży: Paweł VI (1967), Jan Paweł II (1979) oraz Benedykt XVI (2006) (www 4). Sanktuarium jest obecnie pod opieką kapucynów.

Wikariat apostolski Anatolii obejmuje swym zasięgiem największy obszar (48 prowincji) w środkowej i wschodniej Turcji (ryc. 2). Liczbę wiernych szacuje się tu na 2800 osób. Podzielony jest na sześć parafii, w których działa siedem kościołów (tab. 2). Parafie opiekują się i udostępniają swoje świątynie również katolikom innych obrządków, którzy na tym terenie nie posiadają swoich obiektów. Od 2000 r. siedzibą wikariatu jest prokatedra pw. Wniebowzięcia Najświętszej Maryi Panny w Iskanderun. Rangę prokatedry pełni również wcześniejsza siedziba biskupa, konkatedra św. Antoniego z Padwy w Mersin. Warto w tym miejscu wspomnieć, że w czerwcu 2010 r. ówczesny wikariusz Luigi Padovese, biskup Iskanderun i przewodniczący Episkopatu Turcji, został zamordowany przez swojego wieloletniego kierowcę, obywatela Turcji. Przyczyny zbrodni nie są do tej pory znane, choć niektóre tureckie media pisały o motywach na tle religijnym (www 7).

\subsection{Podział terytorialny katolickich Kościołów wschodnich}

Struktura terytorialna i organizacyjna katolickich Kościołów wschodnich jest zróżnicowana i zależy od uwarunkowań historycznych oraz ich statusu prawnego zapisanego w Kodeksie Kanonów Kościołów Wschodnich (Nitkiewicz 2014). W Turcji ze względu na niedużą liczbę wiernych struktury terytorialne tych Kościołów są słabo rozwinięte. Każdy z nich posiada obecnie tylko jedną 


\begin{tabular}{|c|c|c|c|c|c|c|c|c|c|c|c|c|c|c|c|c|c|c|}
\hline$\stackrel{\otimes}{\underline{\Xi}}$ & 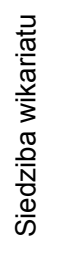 & & & 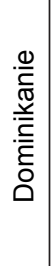 & & & 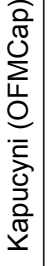 & 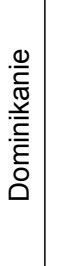 & 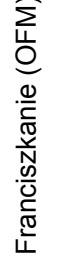 & & & & & 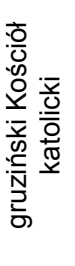 & 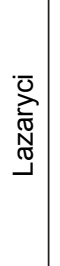 & 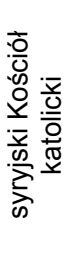 & 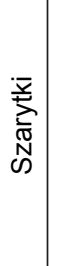 & \\
\hline 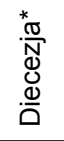 & $\frac{\infty}{3}$ & $\sum_{3}^{\infty}$ & $\mid \begin{array}{l}0 \\
3 \\
3\end{array}$ & $\sum_{3}^{\infty}$ & $\mid \begin{array}{l}0 \\
\vdots \\
3\end{array}$ & $\mid \begin{array}{l}0 \\
0 \\
3\end{array}$ & $\stackrel{n}{3}$ & $\stackrel{n}{3}$ & $\frac{\infty}{3}$ & $\sum_{3}^{\infty}$ & $\mid \begin{array}{l}0 \\
\vdots \\
3\end{array}$ & \begin{tabular}{l}
0 \\
\multirow{3}{3}{}
\end{tabular} & $\stackrel{n}{3}$ & $\overbrace{3}^{\infty}$ & 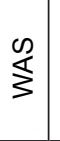 & $\frac{n}{3}$ & $\underset{⿱}{0}$ & $\overbrace{3}^{0}$ \\
\hline 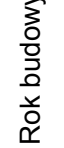 & $\begin{array}{l}0 \\
\stackrel{\infty}{\infty}\end{array}$ & $\stackrel{N}{\sigma}$ & $\begin{array}{l}\stackrel{\mathscr{Q}}{2} \\
\stackrel{2}{2}\end{array}$ & $\begin{array}{l}\underset{m}{\infty} \\
\underset{\infty}{-}\end{array}$ & \begin{tabular}{l}
8 \\
\hdashline \\
-
\end{tabular} & 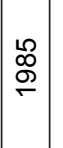 & $\begin{array}{l}\stackrel{0}{0} \\
\stackrel{\infty}{-}\end{array}$ & ' & 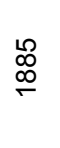 & $\begin{array}{l}\bigotimes \\
\stackrel{0}{\leftarrow}\end{array}$ & $\frac{5}{\sigma}$ & $\begin{array}{c}\bar{x} \\
\stackrel{\infty}{c}\end{array}$ & 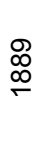 & $\begin{array}{l}\bar{\varnothing} \\
\stackrel{\infty}{\circ}\end{array}$ & 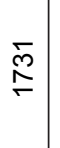 & $\underset{乛}{\stackrel{乛}{*}}$ & $\begin{array}{l}3 \\
x \\
x\end{array}$ & 0 \\
\hline
\end{tabular}

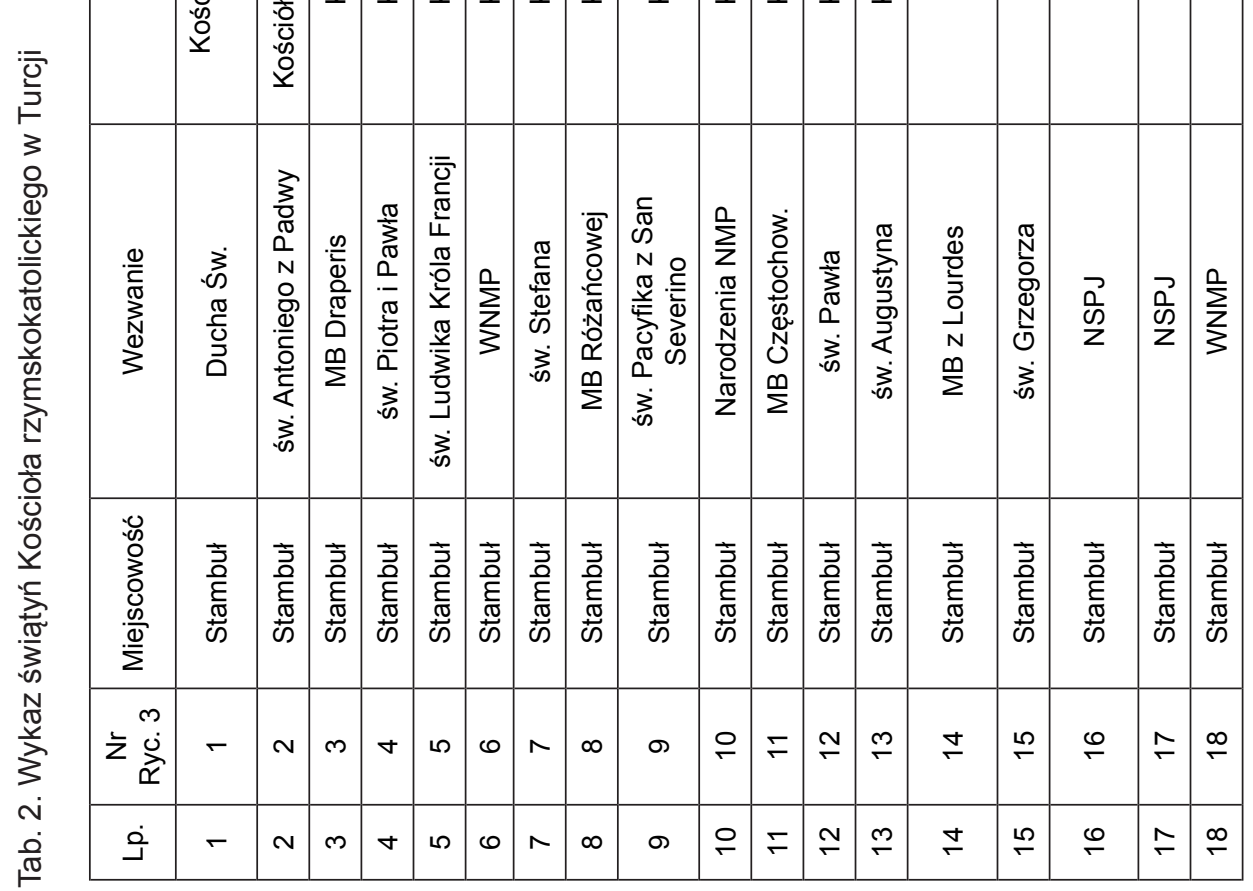




\begin{tabular}{|c|c|c|c|c|c|c|c|c|c|c|c|c|c|c|c|c|c|}
\hline$\underset{\underline{\underline{E}}}{\stackrel{\oplus}{\underline{E}}}$ & 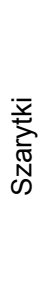 & & 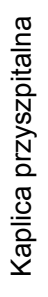 & & & & & 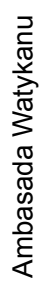 & 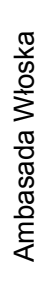 & 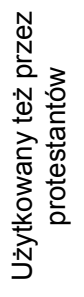 & 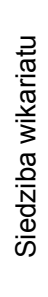 & 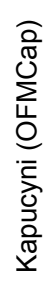 & 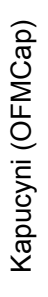 & & 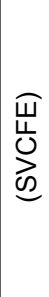 & & \\
\hline 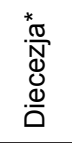 & $\stackrel{\infty}{\frac{1}{3}}$ & $\frac{\infty}{3}$ & $\sum_{3}^{\infty}$ & $\stackrel{\infty}{\infty}$ & $\stackrel{\infty}{\frac{N}{3}}$ & $\stackrel{0}{\frac{1}{3}}$ & $\stackrel{\infty}{\frac{\infty}{3}}$ & $\stackrel{\infty}{\frac{1}{3}}$ & $\stackrel{\infty}{3}$ & $\stackrel{\infty}{3}$ & $\stackrel{\frac{1}{3}}{3}$ & $\stackrel{\frac{1}{4}}{3}$ & $\frac{1}{3}$ & $\frac{5}{3}$ & $\frac{\frac{5}{4}}{3}$ & $\frac{5}{3}$ & $\frac{5}{3}$ \\
\hline 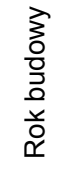 & $\begin{array}{l}\infty \\
\stackrel{\infty}{\infty} \\
\stackrel{\infty}{\leftarrow}\end{array}$ & $\begin{array}{l}\infty \\
\stackrel{\infty}{\infty} \\
\infty\end{array}$ & ' & ' & 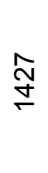 & 0 & 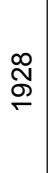 & 0 & 0 & 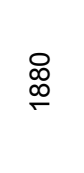 & $\begin{array}{l}\infty \\
\stackrel{\infty}{\infty} \\
\stackrel{\infty}{\Gamma}\end{array}$ & $\begin{array}{l}\widetilde{N} \\
\stackrel{\infty}{\leftarrow}\end{array}$ & $\begin{array}{l}\stackrel{M}{\infty} \\
\stackrel{\infty}{\leftarrow}\end{array}$ & $\begin{array}{l}\stackrel{0}{2} \\
\stackrel{\infty}{\leftarrow}\end{array}$ & 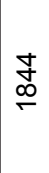 & $\stackrel{\stackrel{\infty}{+}}{\infty}$ & 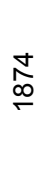 \\
\hline 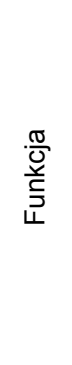 & 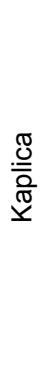 & $\begin{array}{l}\frac{\mathbb{J}}{0} \\
\frac{0}{\overline{0}} \\
\underline{\mathbb{T}}\end{array}$ & 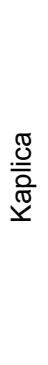 & $\begin{array}{l}\frac{\mathbb{0}}{\bar{O}} \\
\frac{\pi}{\pi} \\
\underline{x}\end{array}$ & 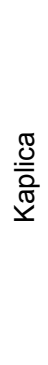 & 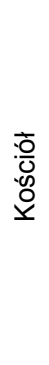 & 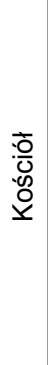 & $\begin{array}{l}\overline{\overline{0}} \\
\frac{0}{0} \\
.00 \\
\stackrel{0}{0}\end{array}$ & $\begin{array}{l}\overline{\overline{0}} \\
\frac{0}{0} \\
.00 \\
\underline{0}\end{array}$ & 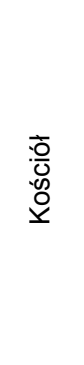 & 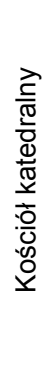 & 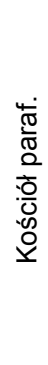 & 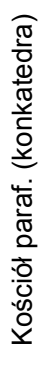 & 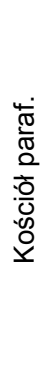 & 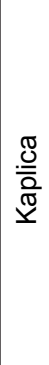 & 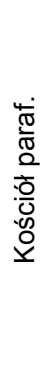 & 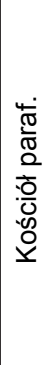 \\
\hline 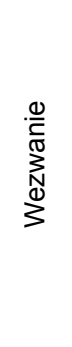 & 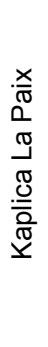 & 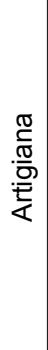 & 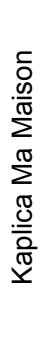 & 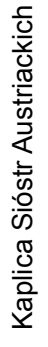 & 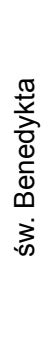 & $\begin{array}{l}\bar{D} \\
\mathbb{D} \\
\stackrel{D}{0} \\
0 \\
0\end{array}$ & 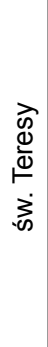 & $\begin{array}{l}\frac{.}{0} \\
\frac{0}{N} \\
\frac{0}{N} \\
:= \\
: \frac{\pi}{2} \\
\sum\end{array}$ & 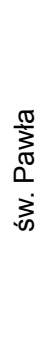 & 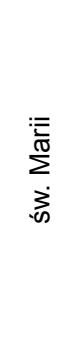 & $\sum_{3}^{0}$ & 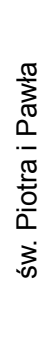 & 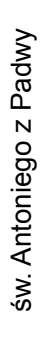 & $\begin{array}{l}\sum_{\pi}^{\infty} \\
0 \\
\sum_{0}^{\infty}\end{array}$ & 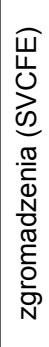 & 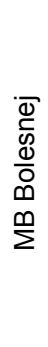 & 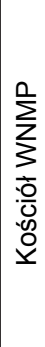 \\
\hline 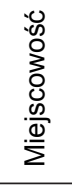 & 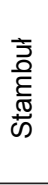 & $\begin{array}{l}\bar{\vdots} \\
\frac{0}{\varepsilon} \\
\frac{\pi}{\sigma} \\
\omega\end{array}$ & 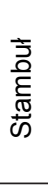 & $\begin{array}{l}\bar{\vdots} \\
\frac{\hbar}{E} \\
\frac{\pi}{\omega} \\
\omega\end{array}$ & $\begin{array}{l}\overline{\overrightarrow{0}} \\
\frac{\vec{E}}{\pi} \\
\dot{\omega}\end{array}$ & $\begin{array}{l}\frac{\widetilde{T}}{\mathbb{W}} \\
\frac{\vec{T}}{\frac{1}{4}}\end{array}$ & 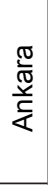 & $\frac{\frac{\pi}{\pi 0}}{\frac{\sqrt{0}}{\frac{\pi}{4}}}$ & $\begin{array}{l}\frac{\sqrt{0}}{\mathbb{N}} \\
\frac{\vec{W}}{\frac{1}{4}}\end{array}$ & 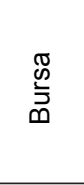 & 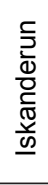 & 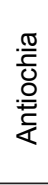 & $\begin{array}{l}\frac{\cdot \frac{5}{\omega n}}{\frac{2}{0}} \\
\sum\end{array}$ & $\begin{array}{l}\frac{\pi}{C} \\
\frac{\pi}{0} \\
\frac{\pi}{4}\end{array}$ & 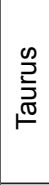 & 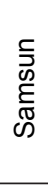 & 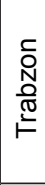 \\
\hline$\sum \stackrel{m}{\dot{\Delta}}$ & $\stackrel{\sigma}{\circ}$ & iे & $\bar{N}$ & $\approx$ & $\stackrel{\widetilde{N}}{\mathrm{~N}}$ & $\stackrel{\searrow}{\sim}$ & $\mathbb{N}$ & $\stackrel{\sim}{N}$ & $\hat{N}$ & $\stackrel{\infty}{N}$ & $\stackrel{N}{N}$ & ింల & $\bar{m}$ & లె & m & లి & $\stackrel{10}{\rho}$ \\
\hline$\stackrel{\dot{9}}{ }$ & 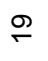 & 尺ి & $\bar{\sim}$ & N & 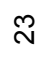 & $\stackrel{\searrow}{\sim}$ & 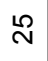 & $\stackrel{\mathscr{N}}{ }$ & $\widehat{N}$ & $\stackrel{\infty}{N}$ & $\stackrel{N}{ }$ & ిల & $\bar{m}$ & లె & ల్ల & లి & 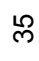 \\
\hline
\end{tabular}




\begin{tabular}{|c|c|c|c|c|c|c|c|c|c|c|c|c|c|c|c|}
\hline$\stackrel{\mathscr{E}}{\underline{E}}$ & & 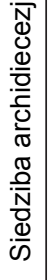 & & 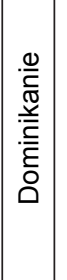 & 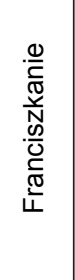 & 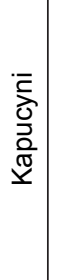 & 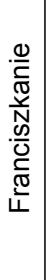 & & & & & & & & \\
\hline 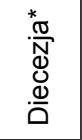 & $\mid \begin{array}{l}\frac{\pi}{3} \\
3\end{array}$ & $\varangle$ & $\bar{\varangle}$ & $\bar{\alpha}$ & $\bar{\varangle}$ & $\bar{\varangle}$ & « & $\bar{\varangle}$ & $\bar{\varangle}$ & $\bar{\varangle}$ & $\bar{\varangle}$ & « & $\bar{\varangle}$ & $\varangle$ & « \\
\hline $\begin{array}{l}\frac{3}{0} \\
\frac{0}{0} \\
\frac{0}{0} \\
\frac{0}{0} \\
\mathbb{x}\end{array}$ & $\mid$\begin{tabular}{l}
0 \\
\multirow{2}{0}{} \\
$\sigma$
\end{tabular} & $\begin{array}{c}\stackrel{+}{\infty} \\
\stackrel{\infty}{\leftarrow}\end{array}$ & $\begin{array}{l}\text { ڤ్ } \\
\stackrel{\leftarrow}{0}\end{array}$ & 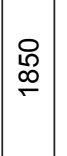 & $\stackrel{\hat{\Omega}}{\stackrel{2}{r}}$ & $\begin{array}{l}\stackrel{\curvearrowright}{\circ} \\
\stackrel{\sigma}{\sigma}\end{array}$ & $\begin{array}{l}\mathscr{D} \\
0 \\
0\end{array}$ & 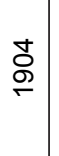 & $\begin{array}{l}\stackrel{0}{\infty} \\
\stackrel{\infty}{\leftarrow}\end{array}$ & §ু & $\stackrel{0}{\circ}$ & $\mid \begin{array}{l}0 \\
\text { Dे } \\
\text { | }\end{array}$ & & $\begin{array}{l}\text { ¿े } \\
\text { ठ̀ }\end{array}$ & 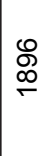 \\
\hline 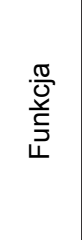 & 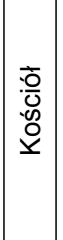 & 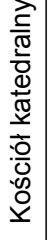 & 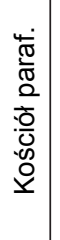 & 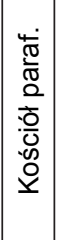 & 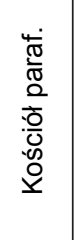 & 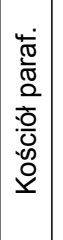 & 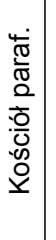 & 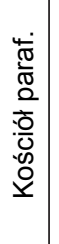 & 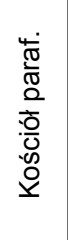 & 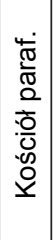 & 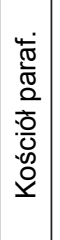 & 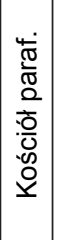 & 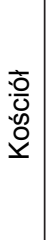 & $\begin{array}{l}: \overline{0} \\
: \underline{0} \\
\underline{0} \\
\underline{y}\end{array}$ & 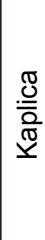 \\
\hline 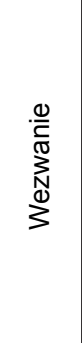 & $\sum_{z}^{0}$ & 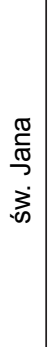 & $\begin{array}{l}\frac{\pi}{2} \\
\frac{2}{\pi} \\
\frac{2}{\overline{0}} \\
0 \\
\frac{3}{\infty}\end{array}$ & 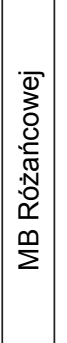 & 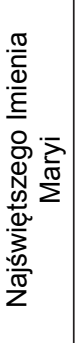 & 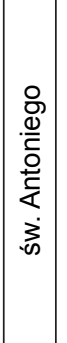 & $\sum_{3}^{0}$ & $\begin{array}{l}\overrightarrow{\vec{d}} \\
\frac{\omega}{\omega} \\
\frac{\omega}{I} \\
\dot{\vec{\omega}}\end{array}$ & 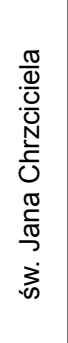 & 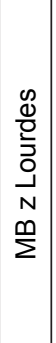 & $\begin{array}{l}\frac{\pi}{3} \\
\sum_{0} \\
0 \\
\dot{3} \\
. \infty\end{array}$ & 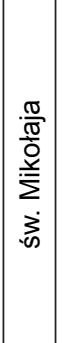 & 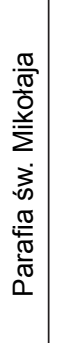 & 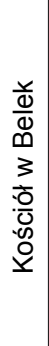 & 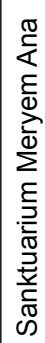 \\
\hline 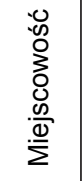 & 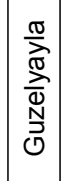 & $\begin{array}{l}\stackrel{\underline{E}}{\underline{\underline{N}}} \\
\underline{\underline{n}}\end{array}$ & $\begin{array}{l}\stackrel{\overline{\mathbf{E}}}{\mathbf{N}} \\
\end{array}$ & $\mid \begin{array}{c}\cdot \overline{\bar{c}} \\
\underline{\underline{N}}\end{array}$ & 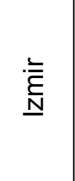 & 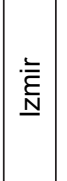 & 产 & 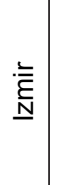 & $\begin{array}{l}\stackrel{\overline{\mathrm{E}}}{\underline{\underline{N}}} \\
\end{array}$ & $\begin{array}{l}\cdot \overline{\bar{t}} \\
\underline{\underline{N}}\end{array}$ & 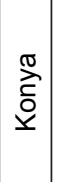 & 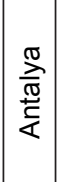 & 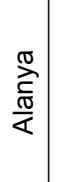 & $\frac{\breve{\omega}}{\stackrel{\varrho}{\Phi}}$ & 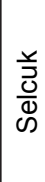 \\
\hline 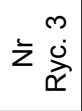 & 足 & $\hat{m}$ & $\stackrel{\infty}{m}$ & 网 & q & $\bar{\gamma}$ & $\mathcal{F}$ & $\stackrel{m}{q}$ & \& & \& & $\mathscr{q}$ & $\hat{q}$ & $\stackrel{\infty}{+}$ & g & in \\
\hline$\dot{9}$ & $\ddot{\infty}$ & $\hat{m}$ & $\stackrel{m}{\infty}$ & ఠ్ల & q & $\check{\sigma}$ & F & $\mathscr{\gamma}$ & $\forall$ & \& & $\mathscr{q}$ & F & $\stackrel{\infty}{\sim}$ & g & is \\
\hline
\end{tabular}


jednostkę administracyjną (tab. 1), która najczęściej obejmuje swoim zasięgiem obszar całego kraju Zazwyczaj mają swoje siedziby i główne świątynie w Stambule. Tu też mieszka zdecydowana większość wiernych. Jednak nie wszystkie Kościoły funkcjonują w normalny sposób. Część ze względu na bardzo małą liczbę wiernych nie posiada swojego biskupa (sede vacante), a czasami nawet stałych kapłanów. Można przyjąć, że mają one charakter historyczny i są najczęściej administrowane przez odpowiednich terytorialnie biskupów rzymskokatolickich (www 4).

Warto również wspomnieć, że oprócz wymienionych wcześniej Kościołów wschodnich od 1861 r. istnieje w Stambule niewielka gruzińska parafia rytu bizantyjskiego należąca do gruzińskiego Kościoła katolickiego, który obecnie pozostaje bez ustalonej hierarchii organizacyjnej. Parafia mieści się w kościele Matki Boskiej z Lourdes (tab. 2) w dzielnicy Şişli (Roberson 1998).

Najbardziej rozbudowany wśród katolickich Kościołów wschodnich jest ormiański Kościół katolicki. Archieparchia ${ }^{3}$ Konstantynopola obejmuje swoim zasięgiem obszar całego kraju i obecnie podlega metropolii patriarchatu cylicyjskiego, na czele którego stoi patriarcha całego Kościoła katolickiego obrządku ormiańskiego (www 4). W granicach archieparchii funkcjonuje 13 kościołów, z czego jeden znajduje się w Mardin, natomiast pozostałe w Stambule (tab. 3). Większość ormiańskich świątyń zlokalizowana jest w trzech dzielnicach Stambułu: Beyoğlu, Beşiktaş oraz Sarıyer (ryc. 3, tab. 3). Oficjalnie archieparchia jest podzielona na 10 parafii, do których należy 3200 ormiańskich katolików. Są to głównie mieszkańcy Stambułu oraz kilka rodzin mieszkających w Ankarze i Mardin (www 8).

Pierwotnie archieparchia Konstantynopola powstała w 1830 r. i działała do 1867 r. Wtedy to, w związku z decyzją papieża Piusa IX o przeniesieniu siedziby patriarchy z Bejrutu (Liban) do Konstantynopola, arcybiskupstwo zostało bezpośrednio włączone do patriarchatu Cylicji. Jednym z powodów przeniesienia siedziby patriarchy był fakt, że w Konstantynopolu w tym czasie mieszkała najliczniejsza wspólnota Ormian, poza tym było to duże centrum kulturalne, religijne i polityczne, dzięki czemu patriarcha mógł liczyć na większe wpływy i kontakty z władcami imperium. W 1928 r. siedzibę patriarchy z powrotem przeniesiono do Bejrutu, a w Konstantynopolu przywrócono arcybiskupstwo. Było to związane ze znacznym spadkiem liczby ormiańskich katolików w Turcji (Roberson 1998).

Jeszcze przed I wojną światową na terenie imperium osmańskiego mieszkała duża mniejszość ormiańska różnych wyznań. Znaczną grupę stanowili katolicy, według danych z 1906 r. około 90 tys. osób (Shaw 1978). W tamtym okresie

3 W katolickich Kościołach wschodnich odpowiednik rzymskokatolickiej archidiecezji. 
Kościół katolicki obrządku ormiańskiego miał bardzo dobrze rozbudowane struktury organizacyjne. W obecnych granicach Turcji istniały trzy archidiecezje, 11 diecezji oraz trzy wikariaty patriarsze. Działało 156 kościołów, 32 klasztory, sześć seminariów oraz 148 szkół katolicko-ormiańskich (www 8). Niestety większość Ormian, w tym również katolików, została zabita lub uciekła z Turcji w czasie ludobójstwa w latach 1915-1917. Mordowano przede wszystkim inteligencję: prawników, lekarzy oraz duchowieństwo. Niszczono również wszelkie elementy związane z kulturą ormiańską. Większość kościołów ormiańskich zburzono lub zamieniono na meczety, podobnie świątynie i obiekty kultowe innych narodowości i religii. Władze tureckie do tej pory nie przyznają się do ludobójstwa Ormian i pozostałych mniejszości narodowych z czasów I wojny światowej. Podobnie zresztą uważa większość społeczeństwa tureckiego, kwestia ta pozostaje w Turcji wciąż tematem tabu (Kévorkian 2011).

Na terenie Turcji obecny jest również Kościół katolicki obrządku syryjskiego. Posiada on tylko jedną jednostkę administracyjną - egzarchat ${ }^{4}$ patriarszy Turcji z siedzibą w Stambule. Egzarchat nie należy do żadnej większej prowincji kościelnej i bezpośrednio podlega syryjsko-katolickiemu patriarsze antiocheńskiemu, który ma obecnie siedzibe w Bejrucie. Powstał stosunkowo niedawno, bo dopiero w 1991 r. Od tego czasu nie udało się obsadzić urzędu biskupa, a jego obowiązki nieprzerwanie sprawuje prałat Yusuf Sağ (www 4). Według danych watykańskich z 2014 r. do egzarchatu należało 2 tys. wiernych (tab. 1), którzy do dyspozycji mieli trzy kościoły: w Stambule, Mardin i Iskanderun (tab. 3).

Podobnie jak w przypadku Kościoła ormiańskokatolickiego, również Kościół syryjskokatolicki w czasach imperium osmańskiego miał o wiele większą liczbę wiernych i dużo lepiej rozwinięte struktury administracyjno-organizacyjne. Świadczy o tym choćby fakt, że od 1850 r. w Mardin swoją siedzibę miał patriarcha tego Kościoła. Jednak na początku lat 20. XX w. przeniósł się do Bejrutu, dokąd po I wojnie światowej wyemigrowało wielu syryjskich katolików (Roberson 1998). W czasie ludobójstwa Ormian prześladowani byli także syryjscy katolicy. Osoby, które wtedy przeżyły schroniły się na terenach dzisiejszej Syrii, Iraku oraz Libanu (Kévorkian 2011). Obecnie w związku z wojną domową w Syrii i Iraku duża część chrześcijan (w tym syryjskich i ormiańskich katolików) ucieka przed prześladowaniami, najczęściej udając się do Turcji. Szacuje się, że dotychczas do Turcji przybyło około 45 tys. chrześcijańskich uchodźców. Jednak większość

4 Jest to odpowiednik rzymskokatolickiego wikariatu apostolskiego. 
z nich w obawie przed prześladowaniami ze strony Turków nie przyznaje się do swego pochodzenia i religii. Część z nich bowiem to potomkowie rodzin, które zbiegły przed ludobójstwem w czasie I wojny światowej (www 9).

Kościół katolicki obrządku greckiego (bizantyjskiego) działa w Turcji od 1911 r. Wówczas papież Pius X powołał w imperium osmańskim specjalny ordynariat dla greckich katolików, na podstawie którego powstał w Konstantynopolu egzarchat apostolski. W latach 1932-1936 nastąpiła krótka przerwa w działalności stambulskiego egzarchatu, obszar ten był wtedy administrowany przez egzarchat apostolski Grecji z siedzibą w Atenach. Od 1957 r. diecezja nie ma swojego biskupa, a od kilku lat nie ma również żadnego stałego kapłana (Nitkiewicz 2014). Obecnie istnieje tylko jedna mała parafia w Stambule. W ramach tej parafii działa jeden kościół - grecka katedra Najświętszej Maryi Panny w Stambule (tur. Ayatriada Rum Katoliki Kilise), która oficjalnie jest siedzibą biskupa (tab. 3). Od 1999 r. opieką oraz administracją Kościoła greckokatolickiego zajmuje się rzymskokatolicki ordynariusz wikariatu apostolskiego Stambułu (www 4).

Cała wspólnota bizantyjskich katolików jest stosunkowo mała i w 2014 r. liczyła 6025 wiernych, z czego większość mieszkała w Grecji (Nitkiewicz 2014). W Turcji żyje obecnie tylko kilka rodzin greckokatolickich (ok. 20 osób). Według danych Watykanu na początku lat 50. XX wieku w Stambule mieszkało około tysiąca greckich katolików, jednak w kolejnych latach liczba ta dramatycznie się zmniejszała (www 1). Było to związane z wydarzeniami w 1955 r., kiedy z inspiracji władz tureckich zorganizowano i przeprowadzono w stolicy pogrom mniejszości narodowych, głównie Greków, Żydów i Ormian. Po tych wydarzeniach większość mieszkańców Stambułu pochodzenia greckiego oraz pozostałych mniejszości narodowych porzuciła swoje domy i uciekła z Turcji (Kołodziejczyk 2011).

Oficjalnie nad Bosforem swoją siedzibę ma także egzarchat patriarszy Stambułu należący do Greckiego Melchickiego Kościoła Katolickiego, zwanego też Kościołem melchickim. Egzarchat został ustanowiony w 1911 r. i w rzeczywistości działał do 1955 r., kiedy to w czasie pogromów w Stambule została zniszczona katedra melchicka, a większość wiernych i ówczesny biskup wyjechali z Turcji. W związku z tym Kościół ten nie posiada obecnie żadnej świątyni ani żadnego stałego kapłana (tab. 1) i podobnie jak w przypadku greckich katolików opieke oraz administrowanie nim powierzono wikariuszowi apostolskiemu Stambułu. Siedziba egzarchatu znajduje się w rzymskokatolickiej katedrze Ducha Św., tam też odprawiane są msze święte dla nielicznej grupy wiernych, szacowanej na ok. 20 osób (www 4). 


\begin{tabular}{|c|c|c|c|c|c|c|c|c|c|c|c|c|c|c|c|}
\hline 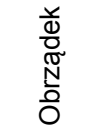 & 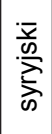 & 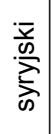 & 竞 & 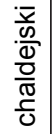 & 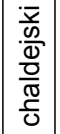 & \begin{tabular}{|l|}
$\vec{u}$ \\
$\bar{d}$ \\
$\stackrel{\bar{v}}{\sigma}$
\end{tabular} & 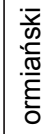 & 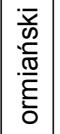 & 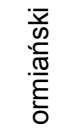 & 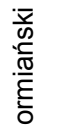 & 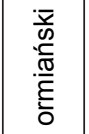 & 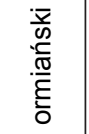 & 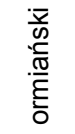 & 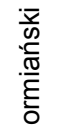 & 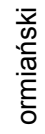 \\
\hline 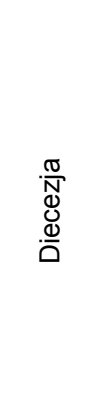 & 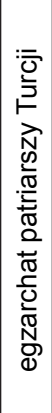 & 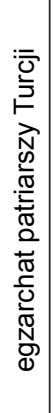 & 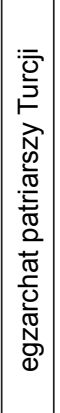 & 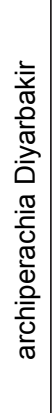 & 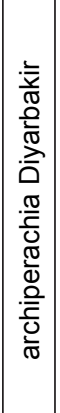 & 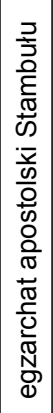 & 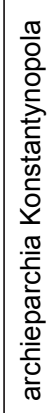 & 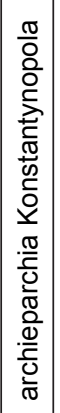 & 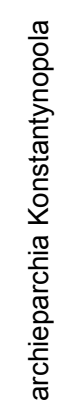 & 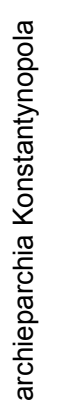 & 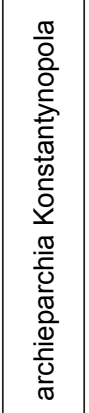 & 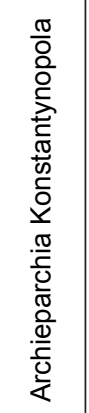 & 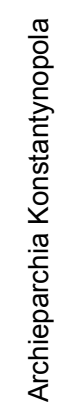 & 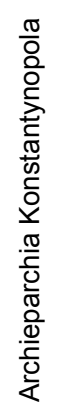 & 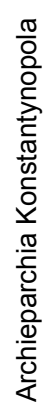 \\
\hline 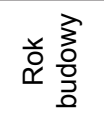 & & $\begin{array}{l}\mathbb{J} \\
\stackrel{\infty}{c}\end{array}$ & 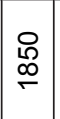 & $\stackrel{3}{3}_{3}^{3}$ & 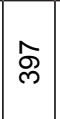 & $\begin{array}{c}\underset{0}{\infty} \\
\infty \\
\sim\end{array}$ & \begin{tabular}{|l}
$\stackrel{\otimes}{\circ}$ \\
$\stackrel{0}{\circ}$
\end{tabular} & \begin{tabular}{|l|}
$\hat{\infty}$ \\
$\stackrel{\infty}{\sim}$
\end{tabular} & 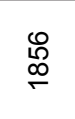 & $\stackrel{\stackrel{\mathscr{O}}{\circ}}{=}$ & $\begin{array}{l}\bigotimes \\
\nsubseteq \\
\leftarrow\end{array}$ & $\underset{\infty}{\widetilde{\infty}}$ & $\underset{\stackrel{\infty}{\infty}}{\stackrel{\infty}{\leftarrow}}$ & $\underset{\infty}{\stackrel{\infty}{\infty}}$ & 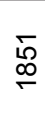 \\
\hline $\begin{array}{l}\frac{\sigma}{0} \\
\frac{\vec{v}}{5} \\
\overrightarrow{5}\end{array}$ & 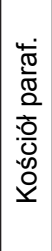 & 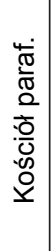 & 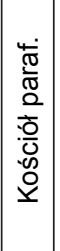 & 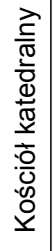 & 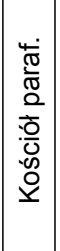 & 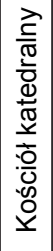 & 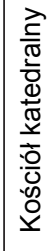 & 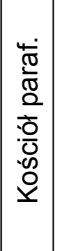 & 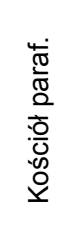 & 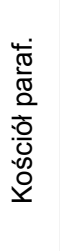 & 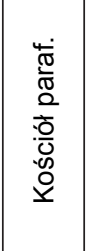 & 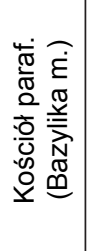 & 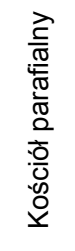 & 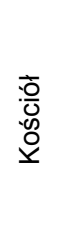 & 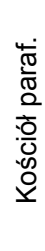 \\
\hline 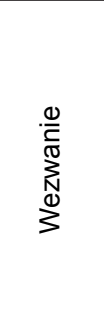 & $\frac{\overrightarrow{0}}{0}$ & $\sum_{z}^{0}$ & 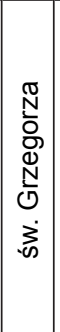 & $\sum_{z}^{n}$ & 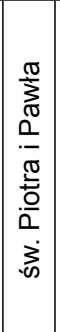 & 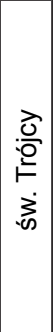 & 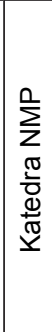 & 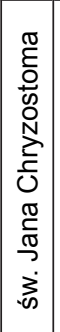 & 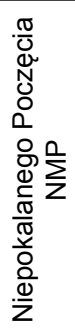 & 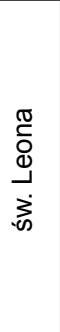 & 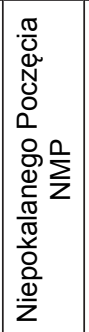 & 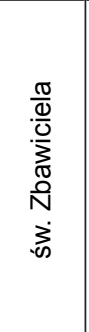 & 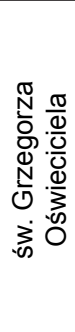 & 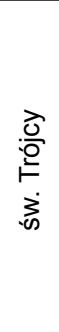 & $\begin{array}{l}\frac{\pi}{3} \\
\sum_{0} \\
0 \\
.3 \\
.0\end{array}$ \\
\hline 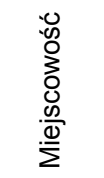 & $\begin{array}{l}\overline{\vec{z}} \\
\text { है } \\
\text { 离 } \\
\dot{\omega}\end{array}$ & $\begin{array}{l}\frac{5}{\frac{5}{0}} \\
\frac{\pi}{20} \\
\sum\end{array}$ & 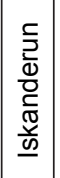 & 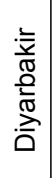 & 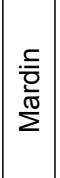 & 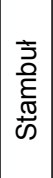 & 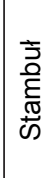 & $\mid$\begin{tabular}{l|}
$\bar{z}$ \\
$\underline{0}$ \\
$\tilde{E}$ \\
$\tilde{\Phi}$ \\
$\omega$ \\
$\omega$
\end{tabular} & 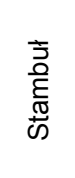 & 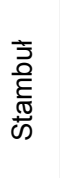 & 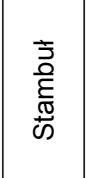 & $\begin{array}{l}\overline{\bar{z}} \\
\text { है } \\
\text { त्ञ } \\
\text { के }\end{array}$ & $\begin{array}{l}\overline{\bar{z}} \\
\text { है } \\
\text { E्ञ } \\
\text { के }\end{array}$ & $\begin{array}{l}\overline{\bar{z}} \\
\stackrel{\vec{E}}{E} \\
\text { ஸा } \\
\dot{\omega}\end{array}$ & 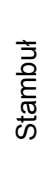 \\
\hline 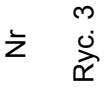 & is & N & ณ̈ & 茄 & 吕 & i & $\hat{n}$ & $\mid$\begin{tabular}{l}
$\infty$ \\
$i$ \\
\hdashline
\end{tabular} & i & 8 & $\overline{0}$ & $\widetilde{0}$ & $\ddot{8}$ & đ & $\stackrel{8}{0}$ \\
\hline$\dot{9}$ & - & $\sim$ & $m$ & $\nabla$ & o & 0 & $\wedge$ & $\infty$ & $\sigma$ & 음 & $F$ & $\simeq$ & $\stackrel{m}{=}$ & $\underset{\leftarrow}{\ddagger}$ & $\stackrel{\text { م }}{2}$ \\
\hline
\end{tabular}




\begin{tabular}{|c|c|c|c|c|}
\hline $\begin{array}{l}\frac{v}{0} \\
\frac{0}{0} \\
N \\
\text { Oे }\end{array}$ & 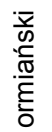 & 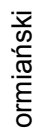 & 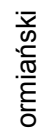 & 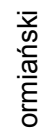 \\
\hline 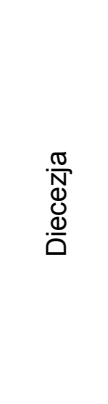 & 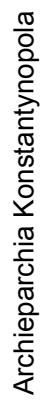 & 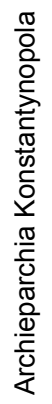 & 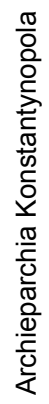 & 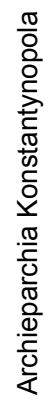 \\
\hline 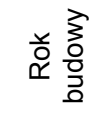 & $\begin{array}{l}\infty \\
\stackrel{\infty}{\infty} \\
\infty\end{array}$ & $\begin{array}{l} \\
\nsubseteq \\
\infty\end{array}$ & $\underset{\infty}{\Gamma}$ & $\begin{array}{l}\text { চ } \\
\stackrel{\infty}{\leftarrow}\end{array}$ \\
\hline $\begin{array}{l}\frac{\sqrt{0}}{N} \\
\frac{1}{5} \\
\overrightarrow{4}\end{array}$ & $\begin{array}{l}\frac{1}{\pi} \\
\frac{\pi}{\pi} \\
\frac{0}{0} \\
\frac{0}{0} \\
\frac{0}{0} \\
\stackrel{0}{0}\end{array}$ & $\begin{array}{l}\overline{0} \\
: \overline{0} \\
.00 \\
\underline{0} \\
\underline{x}\end{array}$ & $\begin{array}{l}\overline{0} \\
: 0 \\
0 \\
0 \\
\underline{y}\end{array}$ & 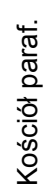 \\
\hline 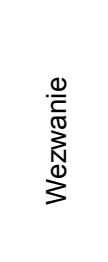 & $\sum_{\vdots}^{0}$ & 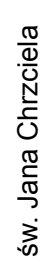 & 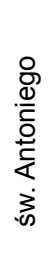 & 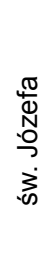 \\
\hline 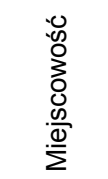 & 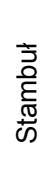 & 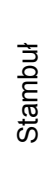 & 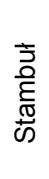 & $\begin{array}{l}\frac{.5}{\overline{0}} \\
\frac{\pi}{20}\end{array}$ \\
\hline$\dot{m} \stackrel{m}{\stackrel{0}{\vec{x}}}$ & $\varnothing$ & $\hat{0}$ & \&్ర & 8 \\
\hline$\stackrel{\dot{9}}{ }$ & $\stackrel{\oplus}{\sim}$ & 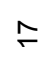 & $\stackrel{\infty}{\Gamma}$ & $\stackrel{9}{\square}$ \\
\hline
\end{tabular}


Chaldejski Kościół katolicki ma najstarsze struktury terytorialne spośród wszystkich katolickich Kościołów wschodnich w Turcji. Już w 1553 r. w Diyarbakır (Amida) została utworzona eparchia. Działała ona nieprzerwanie do 1929 r., w latach 1929-1966 w związku z nieobsadzeniem urzędu eparchy została zlikwidowana. W 1966 r. została przywrócona i podniesiona do rangi archieparchii. Jest to obecnie jedyna jednostka administracyjna Kościoła chaldejskiego w Turcji i podlega chaldejskiemu patriarchatowi Babilonu z siedzibą w Bagdadzie. Od 2005 r., po śmierci ostatniego archieparchy, urząd ten nie jest obsadzony, a jednostkę administruje prałat François Yakan, który rezyduje w Stambule (www 4). Liczbę wiernych szacuje się na 7640 osób (tab. 1). Oficjalnie archieparchia jest podzielona na 9 parafii. Są to jednak w większości parafie historyczne, ponieważ aktualnie działają tylko dwa kościoły - w Diyarbakır i Mardin (tab. 3). Chaldejscy katolicy mieszkający w Stambule korzystają z innych świątyń katolickich. Podobnie jak w przypadku pozostałych mniejszości religijnych również chaldejscy katolicy mocno ucierpieli w czasie I wojny światowej (Roberson 1998).

\section{Podsumowanie}

Niekorzystny status mniejszości religijnych w Turcji jest niezmienny od wielu lat. W niełatwej sytuacji jest Kościół rzymskokatolicki obrządku łacińskiego, który mimo stosunkowo dobrze rozbudowanej struktury terytorialnej musi ograniczać swoją działalność w związku z nieuregulowanym statusem prawnym. Jednak w najtrudniejszej sytuacji są obecnie mało liczne grupy wiernych katolickich Kościołów wschodnich. Duża część z nich ze względu na prześladowania już dawno wyemigrowała z Turcji. Natomiast osoby, które zostały, w większości opuścity swoje rdzenne regiony i przeniosły się do większych miast, głównie do Stambułu. Mniejszości religijne są dyskryminowane i ogranicza się im prawo do kultywowania i podtrzymywania swoich tradycji religijnych oraz dysponowania nieruchomościami. W najbliższym czasie niektóre ze katolickich Kościołów wschodnich działających na terenie Turcji mogą przestać istnieć. Wraz z nimi zniknie wielopokoleniowa tradycja i kultura, charakterystyczna dla niektórych regionów Turcji.

Analizując obecną sytuację prawną społeczności niemuzułmańskich w Turcji, można stwierdzić, że nadal obowiązującym dokumentem jest traktat lozański z 1923 r., bardzo niekorzystny dla większości wspólnot wyznaniowych. Zmiany 
tej sytuacji spodziewano się $\mathrm{w}$ działaniach prowadzonych $\mathrm{w}$ ramach akcesji Turcji do UE. Jednak dotychczas zmiany te nie wpłynęły realnie na poprawe pozycji niemuzułmańskich obywateli Turcji. Rozwiązaniu tego problemu nie sprzyja także sytuacja społeczno-polityczna w kraju i w regionie. Od dłuższego czasu widoczna jest tendencja do przyjmowania przez część tureckiego społeczeństwa postaw coraz bardziej radykalnych i konserwatywnych. Najlepiej świadczy o tym fakt, że od 2002 r. władzę nieprzerwanie sprawuje konserwatywnie islamska Partia Sprawiedliwości i Rozwoju (tur. Adalet ve Kalkınma Partisi, AKP). Partia ta jest często krytykowana czy wręcz oskarżana o naruszanie, a nawet chęć likwidacji, tradycyjnego tureckiego modelu świeckiego państwa czy o brutalne rozprawianie się z opozycją i mniejszością kurdyjską. Mimo wielu deklaracji, jakie składała AKP i jej lider oraz obecny prezydent Recep Tayyip Erdogan, Turcja w rzeczywistości nie jest zainteresowana rozwiązaniem sprawy mniejszości religijnych. Rozwiązanie tej kwestii wiązałoby się z poruszeniem drażliwych spraw, zwrotem nieruchomości i odszkodowań, ale przede wszystkim z przyznaniem się do niechlubnych faktów ze swojej historii. Na to władze, jak i społeczeństwo tureckie nie są chyba jeszcze gotowe. Działania rządu tureckiego w ostatnich latach pokazują, że jest wręcz odwrotnie i Turcja zmierza w stronę państwa homogenicznego, w którym prawa człowieka i mniejszości są traktowane instrumentalnie. Można jednak mieć nadzieję, że mimo to, w Turcji będą dokonywały się odpowiednie zmiany nie tylko przepisów prawa, ale także świadomości społeczeństwa, a perspektywa członkostwa w UE lub szerszej współpracy z Europą będzie do tego mocnym impulsem.

\section{Literatura}

Cleave J., Freely J., 2008, Istanbul: city of two continents, Singapur.

Chudziak M., 2016, Turcja ostrzeliwuje Kurdów syryjskich, Analizy OSW, http://www. osw.waw.pl/pl/publikacje/analizy/2016-02-17/turcja-ostrzeliwuje-kurdow-syryjskich (05.01.2016).

International Religious Freedom Report, 2014, www.state.gov/j/drl/rls/irf/religiousfreedom (02.07.2015).

Jarosiewicz A., Strachota K., 2015, Turcja a problem uchodźców syryjskich, „Komentarze OSW", nr 186, Ośrodek Studiów Wschodnich, http://www.osw.waw.pl/sites/ default/files/komentarze_186.pdf (05.01.2016). 
Haynes J., 2010, Politics, identity and religious nationalism in Turkey: from Ataturk to the AKP, „Australian Journal of International Affairs”, 64 (3), s. 312-327.

Hovyan V., 2013, Issue of returning church properties in Turkey, „Globus Analytical Journal", 1/2013:http://www.noravank.am/eng/articles/detail.php?ELEMENT_ $\mathrm{ID}=6891(05.10 .2015)$.

Karpat K.H., 1985, Ottoman population, 1830-1914: demographic and social characteristics, Wis: University of Wisconsin Pres, Madison.

Kévorkian R., 2011, The Armenian genocide: a complete history, I.B. Tauris, London. Kołodziejczyk D., 2011, Turcja, Wyd. Trio, Warszawa.

Kościelniak K., 2010, Organizacja, kondycja i problemy mniejszości religijnych $w$ Turcji, [w:] K. Kościelniak (red.), Państwo wspólnota i religia - wybrane zagadania procesów modernizacji na Bliskim Wschodzie, Wyd. UNUM, Kraków, s. 249-280.

Nitkiewicz K., 2014, Katolickie Kościoły Wschodnie, Wyd. Diecezjalne i Drukarnia w Sandomierzu, Sandomierz.

Oehring O., 2004, Human rights in Turkey - secularism: religious freedom? Missio, Aachen.

Özgül C., 2014, Legally Armenian: tolerance, conversion, and name change in Turkish courts, „Comparative Studies in Society and History”, 56 (3), s. 622-649.

Roberson R. G., 1998, Chrześcijańskie Kościoły Wschodnie, Wyd. Homini, Bydgoszcz.

Shaw S.J., 1978, The Ottoman census system and population 1831-1914, „International Journal of Middle East Studies", 9 (3), s. 325-338.

Strachota K., 2015, Irak - nowy front dla Turcji?, Analizy OSW, http://www.osw.waw. $\mathrm{pl} / \mathrm{pl} /$ publikacje/analizy/2015-12-09/irak-nowy-front-dla-turcji (20.11.2015).

Szymański A. (red.), 2011, Turcja i Europa - wyzwania i szanse, Polski Instytut Spraw Międzynarodowych, Warszawa.

Tokats S., Aras B., 2009, The EU and minority rights in Turkey, „Political Science Quarterly", 124 (4), s. 697-720.

Wódka J., 2012, Polityka zagraniczna Turcji - uwarunkowania wewnętrzne oraz podmioty decyzyjne, Wyd. Trio, Warszawa.

Yildiz I., 2007, Minority rights in Turkey, „Brigham Young University Law Review”, 3, s. 791-812.

Yilmaz G., 2012, Exploring the implementation of minority protection rules in the 'worlds of compliance': the case of Turkey, „Perspectives on European Politics and Society", 13 (4), s. 408-424.

Zeidan D., 1999, The Alevi of Anatolia, „Middle East Review of International Affairs”, 3 (4), s. 74-89. 


\section{Strony internetowe}

www 1: http://www.catholic-hierarchy.org_(05.10.2015).

www 2: http://www.asianews.it/news-en/Turkish-Catholic-Church-calls-for-a-return-of200-properties.-Better-to-ask-for-legal-recognition-24576.html (30.09.2015).

www 3: http://www.katolikkilisesi.org (10.10.2015).

www 4: http://www.gcatholic.org_(05.10.2015).

www 5: http://www.vatican.va/roman_curia/congregations/orientchurch/index_it.htm (05.10.2015).

www 6: http://www.meryemana.info_(10.10.2015).

www 7: http://www.hurriyetdailynews.com/fifteen-year-sentence-for-killing-of-bishop, .aspx?pageID=238\&nID=39693\&NewsCatID=341 (09.09.2015).

www 8: http://www.armeniancatholic.org/inside.php?lang=en\&page_id=315_

(09.09.2015).

www 9: http://www.hurriyetdailynews.com/christian-refugees-face-difficulties-hide-religion-in-turkey-.aspx?pageID=238\&nID=92719\&NewsCatID=339 (09.02.2016).

Michat Jakiel, mgr

Instytut Geografii i Gospodarki Przestrzennej

Uniwersytet Jagielloński w Krakowie

e-mail:michal.jakiel@uj.edu.pl 
